\title{
Childhood Depression as Emerging Public Health Problem: a Systematic Review
}

Nádia Nara Rolim Lima1,4, João Vitor Cândido Pimentel², Cícero Roberto Pinheiro Grangeiro Júnior², Antonio Gilvan Teixeira Júnior ${ }^{2}$, Matheus Felipe Aguiar Santos², Camilla Barros Meireles², Laís Chaves Maia2, Victoria Aline Linhares Miná2 , Paula Pessoa Pinheiro ${ }^{2}$, Marcos Aurélio Moreira Pereira ${ }^{3}$, Ângelo Roncalli Ramalho Sampaio², Thércia Lucena Granjeiro Maranhão4, Janaina Batista Pereira4,

Pedro Ivo Martins Cidade ${ }^{5}$, Alberto Olavo Advincula Reis ${ }^{6}$, Modesto Leite Rolim Neto ${ }^{2,4}$, Vânia Barbosa do Nascimento ${ }^{4}$

\section{Abstract}

As an important problem of public health, the childhood depression deserves special attention, in which the serious and long term consequences of the disease weigh to the childhood development. Taking this in consideration, the present study was based in the following research question: which practical contribution the actual scientific literature about childhood depression has to offer to clinicians and researchers? The aim of the present study was to evaluate the actual evidence concerning the different aspects (etiology/risk factors, diagnosis, treatment, prognostic and prevention) of childhood depression, with the purpose to systematize such evidences and to contribute with the knowledge about the problem. In way to reach this aim, it was performed a systematic review of articles about childhood depression, in the period from January first of 2010 to January 16 of 2014, in the databases PubMED, MEDLINE and SciELO. In the research, the following terms were used: "depression" (MeSH), "child" (MeSH) and "childhood depression" (Keyword). Of the 860 found studies, 76 met the eligibility criteria. The found studies covered a wide variety of aspects related to childhood depression, as diagnosis, treatment, prevention and prognostic. The actual scientific literature about the childhood depression converges to, directly or not, highlight the negative impacts of the depression disorders to the life quality of the children. Unfortunately, the found studies show that the childhood depression is a disorder that develops most commonly in a poverty and vulnerability scenery, where the individual and familiar necessities concerning the childhood depression are not always taken in consideration. In this context, this review demonstrates that the depression started in
1 Pos-Graduation Program in Neuropsychiatry, Federal University of Pernambuco - UFPE, Recife, Pernambuco, Brazil.

2 Faculty of Medicine, Federal University of Cariri - UFCA, Barbalha, Ceará, Brazil.

3 Faculty of Medicine, University of Rio Verde - UniRV, Rio Verde, Goiáis, Brazil.

4 Pos-Graduation Program in Health Sciences, Faculty of Medicine of $A B C$ Santo André, São Paulo, Brazil.

5 Faculty of Medicine Estácio - FMJ, Juazeiro do Norte, Ceará, Brazil.

6 Postgraduate Program in Public Health, University of São Paulo - USP, São Paulo, SP, Brazil.

Contact information:

Modesto Leite Rolim-Neto.

” modestorolim@yahoo.com.br 
the childhood commonly leads to others psychiatric disturbs and comorbidities. Many of the found studies also confirmed the hypothesis that the human element involved in the care, especially the health professionals' team, is still not adequately capacitated to deal with the childhood depression. In this way, additional researches focusing the development of programs destined to prepare health professionals to treat childhood depression are necessary, plus to complementary studies, with bigger and more homogeneous samples, centered in the prevention and in the treatment of childhood depression.

\author{
Keywords \\ Depression; Child; \\ Childhood Depression; \\ Mental Health Disorders.
}

\section{Introduction}

The depression has been shown more evident from the 70's decade, when the interest in the clinic investigation field and in the academic mean increased. In this context, the depression theme in the children's scenery gained notoriety among the studiers and researchers. Since then, the identity of the childhood depression as a clinic form independent from that detected in adults has been discussed. Therefore, the medical notion of the disease has established itself, concomitantly to the consolidation of the child psychiatry as a specialization apart of the adult and pediatric psychiatry.

In the past three decades, public health recognition of depression in children and adolescents has increased significantly [1]. The depressive disorder in children and adolescents is a common condition that affects the physical, emotional and social development [2] and frequently persists until the adult age $[3,4]$.

The depression prevalence is estimated at $0.3 \%$ to $7.8 \%$ in children under that 13 years [5-8]. In Brazil, the depression prevalence in childhood is $0.2 \%$ and $7.5 \%$ to those under 14 years, which varies mainly in accord with the used evaluation method [8-11]. With that being said, the incidence of depression among children and adolescents is of great concern because of the acute and lasting consequences associated with depressive disorders [2].
Risk factors include a family history of depression, parental conflict, poor peer relationships, deficits in coping skills, and negative thinking [2]. Besides these factors, several other problems in childhood and adolescence may present as depressive symptoms and should always be considered in the differential diagnosis: bereavement or adjustment disorders, oppositional defiant disorder, substance use disorders, hypothyroidism, anemia, infections, cancer, and autoimmune diseases [11].

Regarding the complications of the childhood depression, adverse effects on psychological development, elevated risk of suicide attempts and completion are included $[12,13]$. Besides, the depression in child interferes with school academic progress and with other adaptive functions. Children with depressive disorder have a significant risk of developing Bipolar Disorders, and added comorbid risks [14].

The present study was based in the following research question: which practical contribution the actual scientific literature about childhood depression has to offer to clinicians and researchers? Our hypothesis is that, notwithstanding the growing interest about the theme, the human element involved in the care, especially the health professionals' team, is not adequately capacitated to deal with childhood depression. Our aim was to ascertain evidences concerning to different aspects (etiology/risk factors, diagnosis, treatment, prognosis and 
prevention) of the childhood depression in scientific production, with the purpose to systematize such evidences and to contribute with the knowledge about the problem.

\section{Method}

It was performed a qualitative systematic review of the articles about the theme childhood depression, published in electronic databases previously selected. The qualitative approach was chosen once, regarding the use of quantitative methods, like metaanalysis: a) the necessary information in order to calculate the sample is not available, fact that can limit the analysis to a few quantity of study; the age interval adopted to definition of the term "child" varies a lot among the studies included in the sample, which difficult an adequate comparison from the statistical point of view among the diverse studies.

It was conducted a search in the literature through the online electronic databases PubMED, MEDLINE and SciELO, limiting it to published articles from January 1 of 2010 to January 16 of 2014. The reason to delimitate this time interval (2010-2014) was that, in this period, the theme "depression" gained more space and notoriety in the scientific literature, through several researches posterior to the psychiatric reform. Also, gray literature was used to present important issues related to childhood depression in actuality [1, 21, 185, 192, 194, 237].

In this perspective, it is important to show that from psychiatry to pediatric, new forms of interactions among knowledge gathered more detailed information in relation to social-demographic data, clinical information based in epidemiological data, assistance regime and proceedings. Empirically, it perceives that, since 2010, ethical concerns about public politics directed to mental health in children and adolescents became the focus of the investigations. In this sense, it is from 2010 to the actual moment that the information about the structure, composition and operation related to child mental health services were more clearly delineated, centering in the search of the definition of care in child mental health. The researches of interest about the child mental health, especially those related to childhood depression, are, therefore, centered in the period from 2010 to 2014.

Initially, the following descriptors were used to the search in MEDLINE database:

1. "depression" (Medical Subject Headings [MeSH] descriptor);

2. "child" (Medical Subject Headings [MeSH] descriptor);

3. "childhood depression" (Keyword)

The performed researches were: 1 and 2, 3 . Besides of the MeSH descriptors, it was decided to include the keyword "childhood depression" in the search strategy, although not part of the list of $\mathrm{MeSH}$ descriptors, it is frequently used to describe studies that approach the theme of this review. The search strategy and the articles obtained in the search were revised in two distinct occasions to ensure the adequate selection of the sample and its eligibility.

A similar search strategy was performed in the SciELO (using MeSH and DeCS) and PuMED (MeSH) databases, and equivalents in Portuguese language.

In order to establish a parameter to the limitation of the age group covered by this review, according to "MeSH", the term child refers to the age range from 6 to 12 years old and, consequently, the term "childhood" refers to the study or the time correspondent to this period.

The analysis of the results also followed the ensuing eligibility criteria previously determined. It was adopted the following inclusion criteria:

(1) articles that had in title or in abstract at least one combination of the descripted terms in the search strategy (1 and 2, 3);

(2) publications wrote in English or Portuguese languages;

(3) studies that discussed the childhood depression theme; 
(4) observational prospective and retrospective studies (analytical or descriptive) and clinic essay.

The exclusion criteria were:

(1) other study designs;

(2) non-original studies including editorials, preface, brief communication and letter to editor.

Each article of the sample was read integrally, and the information was inserted in a spread sheet that included authors, publication year, study sample description and main findings. In order to perform a better analysis of the data, the following phase involved a comparison between the studies and their grouping, for heuristic reasons, according the obtained results from each study, in five categories: Etiology/Risk Factors; Diagnosis; Prevention; Prognosis and Treatment.

\section{Results}

Initially, the search strategies previously mentioned resulted in 860 studies. After a title and an abstract analysis of the found articles for eligibility based in inclusion criteria, 784 were excluded and 76 were included in the final sample (Figure 1). (Table 1)

Figure 1: Flow Diagram summarizing the selection process of the included studies of this review.

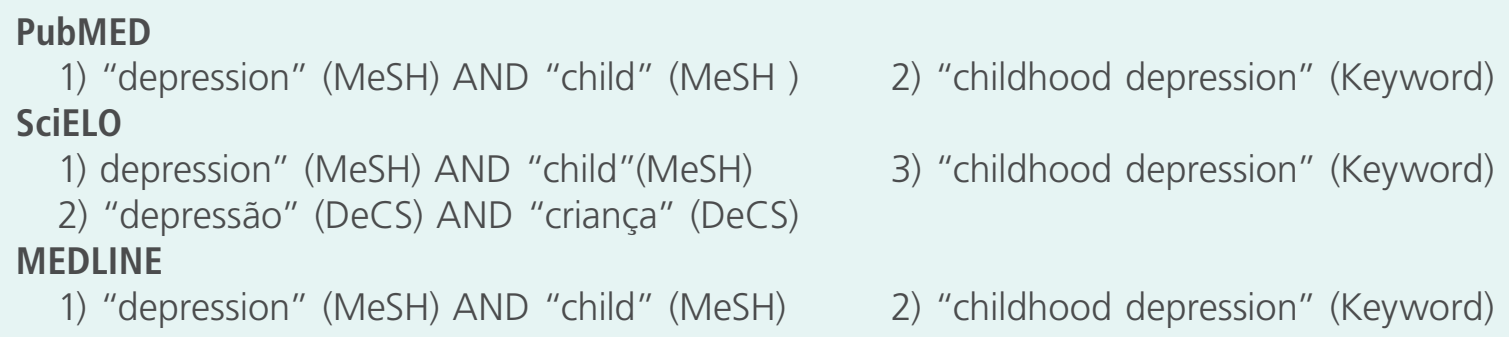

Period: : 01. 01. 2010 to 16.01. 2014

\section{Inclusion criteria}

- Manuscripts in English or Portuguese;

- Childhood Depression;

- Original texts with full online access:

- Prospective or retrospective observational studies (analytical or descriptive) and clinical essays.

860 manuscripts

\section{References with full text analyzed to eligibility:} $(n=76)$

\section{Studies included in the review} $(n=76)$
784 excluded articles after a title and an abstract analysis:

a) Not about childhood depression $(n=415)$;

b) Sample with children aging less that 6 or more than 12 years old $(n=336)$;

c) Literature Review $(n=24)$;

d) Preface $(n=1)$

e) Commentary $(n=1)$;

f) Case Report $(n=3)$;

g) Editorial $(n=2)$;

h) Non-accessible full text $(n=2)$; 
Table 1. Childhood depression - studies and main findings cronologically

\begin{tabular}{|c|c|c|}
\hline Author (Year) & Periodical & Main findings \\
\hline $\begin{array}{l}\text { Rocha et. al. [11], } \\
\qquad(2013)\end{array}$ & $\begin{array}{l}\text { Brazilian Journal of Psychiatry } \\
\text { Pediatric Depression: An } \\
\text { Evidence-Based Update on } \\
\text { Treatment Interventions }\end{array}$ & $\begin{array}{l}\text { Children may have difficulty verbalizing their feelings or may even deny that they are depressed. Thus, special attention } \\
\text { should be given to observable manifestations such as changes in sleep patterns, irritability, poor academic performance, and } \\
\text { social withdrawal. }\end{array}$ \\
\hline $\begin{array}{l}\text { Mc Adams T. A., } \\
\text { Gregory, A. M. \& } \\
\text { Eley [76] (2013) }\end{array}$ & Behavior Genetics & $\begin{array}{l}\text { Multivariate genetic analysis of a sample of teenage twins in the UK, we show that the heritability of putative environmental } \\
\text { measures can be explained by its association with five behavioral phenotypes: oppositionality, defaults, physical aggression, } \\
\text { depression and anxiety. }\end{array}$ \\
\hline $\begin{array}{l}\text { Trompetter I, } \\
\text { Krick B, Weiss G } \\
\text { [251] (2013) }\end{array}$ & $\begin{array}{l}\text { Wiener Medizinische } \\
\text { Wochenschrift. }\end{array}$ & $\begin{array}{l}\text { The tested herbal combination of St. John's Wort, Valerian, and Passionflower offers a good alternative and fulfills the } \\
\text { requested aspects. A good tolerability is represented by just a few mild and transient side-effects. The assessments of parents } \\
\text { and physicians displayed a good efficacy on a broad spectrum of symptoms linked to inclusion diagnosis. }\end{array}$ \\
\hline $\begin{array}{l}\text { Clark et. al.. [2] } \\
\quad(2012)\end{array}$ & American Family Physician & $\begin{array}{l}\text { Pharmacotherapy is recommended for patients with moderate or severe depression. Tricyclic antidepressants are not effective } \\
\text { in children and adolescents. Antidepressants have a boxed warning for the increased risk of suicide; therefore, careful } \\
\text { assessment, follow-up, safety planning, and patient and family education should be included when treatment is initiated. }\end{array}$ \\
\hline $\begin{array}{l}\text { Liu R T et. al.. [81] } \\
\qquad(2012)\end{array}$ & Child Abuse and Neglect & $\begin{array}{l}\text { Childhood Emotional Abuse and Childhood Sexual Abuse experiments of multiple authors increased risk for clinical } \\
\text { depression beyond what is accounted by the total number of types of abuse experiences. This study highlights the need for } \\
\text { future research to assess the specific qualities of childhood abuse that confer risk of exclusivity for clinical depression, as well } \\
\text { as possible mechanisms by which they exert their deleterious effect. }\end{array}$ \\
\hline $\begin{array}{l}\text { Mihalopoulos C. } \\
\text { et. al.. [4] (2012) }\end{array}$ & Pediatrics & $\begin{array}{l}\text { There are a number of effective interventions designed to prevent childhood/adolescent depression. Such interventions tend } \\
\text { to comprise screening and the subsequent provision of psychological therapy. }\end{array}$ \\
\hline
\end{tabular}




\section{Author (Year)}

Banh et. al., [19] (2012)

Agrawal et. al..

[115] (2012)

\section{Lin, F.-G. et. al.}

[162] (2012)

Chen et. al.. [209] Journal of Sleep Research (2012)

Barch et. al., [198] Biological Psychiatry (2012)

Burkhouse et. al. [17], (2012)

Bress et. al. [208], Biological Psychology (2012)

Chua et. al., [210] Singapore Medical Journal (2012)

\section{Periodical}

Journal of Abnormal Child Psychology

Archives of General Psychiatry

Asia Pacific Journal of Clinical Nutrition

Journal of Clinical Child \& Adolescent Psychology

\section{Main findings}

The expression of physical complaints may be a more culturally acceptable method to express depression especially among Hispanic American boys who subscribe to the cultural construct of machismo, where these boys may perceive that the expression of internalizing symptoms would be viewed as a weakness whereas physical complaints would be acceptable. Therefore, from a clinical perspective, attention to reports of physical complaints may be especially important in treating these children as they may be indicative of depression.

The study replicates the buffering effect of the minor allele of rs1049353 (CNR1) on the pathogenic effects of childhood physical abuse on anhedonia. Furthermore, the protective effect of rs1049353 on Major Depressive Disorder was attributable to the presence of anhedonia.

A higher prevalence of depression was found among children in lower Socioeconomic Status (SES) families than in the higher SES group, and results showed the different effects of Body Mass Index (BMI) on childhood depression in the different SES groups.

High-risk girls with no present or past psychopathology reported poorer sleep quality than did low-risk girls. Despite these subjective reports, however, high-risk girls did not differ from their low-risk counterparts in actigraphy- or diary-measured sleep duration, sleep onset latency, WASO, awakenings or snooze duration, or in morning or evening ratings of their mood.

School aged children with a history of PO-MDD show patterns of functional brain responses to emotionally evocative stimuli similar to patterns found in adults and adolescents with major depression. These patterns were most strongly related to the severity of depression during the preschool period, suggesting that the magnitude of early symptoms may be particularly important for understanding altered brain function.

Continued exposure to maternal criticism appears to be an important risk factor for depression in children.

Depression is a major public health concern, and the period from late childhood through early adolescence is a critical time in the development of depressive symptoms.

The drug use must be cautious. The implantation of several therapeutics must take in account the child, the disease context and the family. 


\begin{tabular}{|c|c|c|}
\hline Author (Year) & Periodical & Main findings \\
\hline $\begin{array}{l}\text { Feng et. al., [57] } \\
\qquad(2012)\end{array}$ & $\begin{array}{l}\text { Journal of Abnormal Child } \\
\text { Psychology }\end{array}$ & $\begin{array}{l}\text { Results suggest that right frontal Electroencephalogram asymmetry that is consistent across situations may be an marker of } \\
\text { depression-prone children. }\end{array}$ \\
\hline $\begin{array}{l}\text { Forbes et. al., } \\
\text { [193] (2012) }\end{array}$ & $\begin{array}{l}\text { Journal of Child and Adolescent } \\
\text { Psychopharmacology }\end{array}$ & $\begin{array}{l}\text { The mechanisms for the association between supportive father-child relationships and treatment response could include } \\
\text { fathers' encouragement of engagement in treatment or of strong therapeutic alliance. }\end{array}$ \\
\hline $\begin{array}{l}\text { Kasen et. al., } \\
{[241](2012)}\end{array}$ & Psychological Medicine & $\begin{array}{l}\text { The participation in religious cults and the importance of the religion / spirituality are dealt as potential protection factors that } \\
\text { predict resilience in children and young of high risk. }\end{array}$ \\
\hline $\begin{array}{l}\text { Kösters et. al., } \\
\text { [249] (2012) }\end{array}$ & BMC Public Health & $\begin{array}{l}\text { Application of an intervention in the school setting provides the opportunity to reach large numbers of children in a relatively } \\
\text { safe and non-stigmatizing environment. Easily accessible prevention can be an important strategy to reduce the high } \\
\text { prevalence of anxiety and depression in children. }\end{array}$ \\
\hline $\begin{array}{l}\text { Kovacs et. al., } \\
\text { [191] (2012) }\end{array}$ & $\begin{array}{l}\text { Child \& Adolescent Psychiatric } \\
\text { Clinics of North America }\end{array}$ & $\begin{array}{l}\text { The two major challenges of delivering a clearly articulated, developmentally based intervention for pediatric depression } \\
\text { include the assessment of young patients' developmental stages on the skills of interest and the training of therapists. }\end{array}$ \\
\hline $\begin{array}{l}\text { Pagliaccio et. al., } \\
\text { [189] (2012) }\end{array}$ & $\begin{array}{l}\text { Developmental Cognitive } \\
\text { Neuroscience }\end{array}$ & $\begin{array}{l}\text { This line of evidence would suggest that emotion regulation, rooted in interactions between limbic and prefrontal circuitry, } \\
\text { may be particularly vulnerable to disturbances (e.g. experiences of depression) in early childhood. }\end{array}$ \\
\hline $\begin{array}{l}\text { Pereira et. al., [18] } \\
\qquad(2012)\end{array}$ & BMC Public Health & $\begin{array}{l}\text { Several investigations have demonstrated a wide variation in the prevalence of depression in children and differences } \\
\text { according to the criteria of diagnostic classification adopted, mainly due to the diverse mode of presentation of depression } \\
\text { and the association of this disorder with other psychopathologies. }\end{array}$ \\
\hline $\begin{array}{l}\text { Potter et. al., [58] } \\
\qquad(2012)\end{array}$ & $\begin{array}{l}\text { British Journal of General } \\
\text { Practice }\end{array}$ & $\begin{array}{l}\text { The children of parents with bigger depressive disorder have bigger taxes of psychiatric disorder than the children of } \\
\text { unaffected parents. Furthermore, when depression does arise in the children of parents with depression, evidence suggests } \\
\text { that the course is more severe and impairing. }\end{array}$ \\
\hline $\begin{array}{l}\text { Hyphantis, et. } \\
\text { al.,[153] (2012) }\end{array}$ & Journal of Pediatrics & $\begin{array}{l}\text { Children with neurocargiogenic syncope presented a 2.6-fold higher rate of clinically significant depressive symptoms } \\
\text { compared to healthy controls. }\end{array}$ \\
\hline
\end{tabular}


Author (Year)

Bandiera et. al., [35] (2011)

Cole et. al., [190] (2011)

Rutherford BR et al..[13] (2011)

El-Sheikh M, Arsiwalla DD [132] (2011)

Aderka et. al. [218] (2011)

Fishbein et. al.. [247] (2011)

Journal of Consulting and Clinical Psychology

Addictive Behaviors Academy of Child and Adolescent Psychiatry

Journal of Sleep Research

Findings demonstrate that sleep disruptions (duration, quality) are associated with lower basal Skin Conductance Level (SCL). In the context of sleep problems, a lower level of basal SCL functioned as a vulnerability factor for depression symptoms and worse self-esteem. Further, children with both increased SCL reactivity and sleep problems were at risk for depression symptoms.

Our findings indicate that reciprocal relations exist between posttraumatic and depressive symptoms during treatment, but changes in posttraumatic symptoms lead to changes in depressive symptoms to a greater extent than vice versa.

Preliminary findings in studies done indicate that the onset of drug use during the first adolescence (eg, ages 14-16) can not be tied to immediate proximal disturbances in risk factors, such as traumatic experiences and depressive symptoms. In contrast, the effects of trauma on depression in this sample appears to be confirmed in early childhood (ages 10-14 or younger) and remain relatively stable in middle adolescence when the risk for drug use can be intensified.

Essex MJ et. al.. Development and [51] (2011) $\quad$ Psychopathology
Early Life Stress (ELS) influenced the level of trait-like cortisol and inclination, both hyper- and hypo-arousal evident depending on the ELS. In addition, the type (s) of ELS influenced covariance specific time-HPA functioning and mental health symptoms, with a tighter coupling of the hypothalamic-pituitary-adrenal (HPA) changes with the severity of symptoms among children exposed previously to ELS. 


\begin{tabular}{|c|c|c|}
\hline Author (Year) & Periodical & Main findings \\
\hline $\begin{array}{l}\text { Schoenfelder, } \\
\text { Sandler, Wolchik } \\
\text { \& MacKinnon } \\
\text { [106] (2011) }\end{array}$ & $\begin{array}{l}\text { Journal of Youth and } \\
\text { Adolescence }\end{array}$ & $\begin{array}{l}\text { The most important finding of the study is the significant longitudinal pathway from youth's fear of abandonment during } \\
\text { childhood/adolescence to higher levels of anxiety in romantic relationships six years later, in adolescence/young adulthood, } \\
\text { which, in turn, were associated with higher levels of concurrent self-reports of symptoms of depression. }\end{array}$ \\
\hline $\begin{array}{l}\text { Jones NP et. al.. } \\
\text { [123] (2011) }\end{array}$ & Psychosomatic Medicine & $\begin{array}{l}\text { Inflammatory Bowel Disease (IBD) may be associated with increased sensitivity to negative emotional stimuli above and } \\
\text { beyond depression diagnosis. Depressed youths potentially demonstrate affective blunting, emotional avoidance, or a failure } \\
\text { to regulate emotion after exposure to negative emotional information }\end{array}$ \\
\hline $\begin{array}{l}\text { Benko CR et. al.. } \\
\quad \text { [126] (2011) }\end{array}$ & BMC Pediatrics & $\begin{array}{l}\text { The depressed children consume more caffeinated drinks than non-depressed children. The present study found an } \\
\text { association between the consumption of caffeinated drinks and clinical depression in children. }\end{array}$ \\
\hline $\begin{array}{l}\text { Wakimizu et. al.. } \\
\qquad \text { [161] (2011) }\end{array}$ & BioScience Trends & $\begin{array}{l}\text { This study showed that children with childhood cancer encountered problems in daily life after discharge, including feeling } \\
\text { fatigued and a sense of isolation because of "feeling weak", loss of confidence and difficulty with social interaction due to } \\
\text { "changes in body image", and underachievement, feeling lonely, or feeling anxious due to "inconsistent school attendance } \\
\text { when being treated to prevent infection". }\end{array}$ \\
\hline $\begin{array}{l}\text { Ebesutani et. al.. } \\
\qquad \text { [188] (2011) }\end{array}$ & $\begin{array}{l}\text { Journal of Abnormal Child } \\
\text { Psychology }\end{array}$ & $\begin{array}{l}\text { Specifically, confirmatory factor analysis (CFA) results supported the six-factor The Revised Child Anxiety and Depression } \\
\text { Scale-Parent Version model, which fit equally well across boys and girls as well as across younger and older youth. } \\
\text { The present CFA results did not support combining the Major Depressive Disorder and generalized anxiety disorder (GAD) } \\
\text { scales into a single "distress" factor. }\end{array}$ \\
\hline $\begin{array}{l}\text { Calhoun SL et. } \\
\text { al.. [196] (2011) }\end{array}$ & Sleep Journal & $\begin{array}{l}\text { This study suggests an association between childhood Excessive Daytime Sleepiness (EDS) and medical factors (i.e., heartburn } \\
\text { asthma), medication for asthma, waist circumference, and parent-reported anxiety/depression and sleep difficulties (i.e., } \\
\text { trouble falling asleep, restless sleep, and wakes often during the night). }\end{array}$ \\
\hline $\begin{array}{l}\text { Katz et. al.. [202] } \\
\qquad(2011)\end{array}$ & $\begin{array}{l}\text { Journal of Abnormal Child } \\
\text { Psychology }\end{array}$ & $\begin{array}{l}\text { The current results provide strong support that childhood social withdrawal would serve as a risk factor for adolescent } \\
\text { interpersonal impairment, which would in turn portend risk for depressive symptoms and diagnoses in young adulthood. }\end{array}$ \\
\hline $\begin{array}{l}\text { Allen et. al.. [206] } \\
\qquad(2011)\end{array}$ & $\begin{array}{l}\text { Journal of Child Psychology and } \\
\text { Psychiatry }\end{array}$ & $\begin{array}{l}\text { As expected, we found strong correlations among the two subscales of alexithymia (difficulty identifying feelings - DIF and } \\
\text { difficulty describing feelings - DDF) and measures of depression and somatization. Moreover, results from our test of a } \\
\text { meditational model indicated that depression significantly partially mediated the relationship of DIF/DDF and somatization, } \\
\text { even though the mediation effect remained somewhat small. }\end{array}$ \\
\hline
\end{tabular}




\section{Author (Year)}

Bedi et. al., [82] (2011)

Clavenna et. al., [224] (2011)

Gershon et. al., [70] (2011)

Hanington et. al., Child: Care, Health and

[214] (2011) Development

\section{Periodical} Behavior

International Journal of Eating

Disorders

Journal of Psychiatric Research
Suicide and Life-Threatening

\section{Main findings}

We found that a history of childhood sexual abuse is associated with increased risk of major depressive disorder and suicidal thoughts and behavior including suicidal ideation, persistent suicidal thoughts, suicide plan, and suicide attempt.

The self-criticism is indicated as a powerful mechanism whereby certain forms of maltreatment in childhood can be associated to depressive symptoms and corporal dissatisfaction in patients with binge eating disorder.

The results show that almost a half (45\%) of the daughters of depressed mothers, but none of the daughters of healthy mothers, had developed a psychiatric disorder.

The use of constructive conflict tactics (problem solving, displaying affection, etc.) can have positive effects on children, helping them to develop effective ways of problem solving and dealing with conflict and reducing the chance of behavior problems.

Hipwell et. al. [109], (2011)

Journal of Child Psychology and Psychiatry

Lewis et.al., [62] Journal of the American

Academy of Child \& Adolescent Psychiatry is not accounted for by shared adversity measurements. Girls may be more sensitive to the negative effects of maternal depression symptoms than boys through environmental processes.

Tackett et. al., Journal of the American [79] (2011) Academy of Child \& Adolescent Psychiatry

Negative emotionality represents an important dispositional trait that may explain genetic influences on major depressive disorder-conduct disorder comorbidity, at least for boys. Gender differences require specific research attention, both in terms of dispositional factors as well as developmental progression.

Uher et. al:;[180] Journal of Affective Disorders. (2011)

Wang et. al. [176] (2011)

Journal of Adolescent Health

Weitzman et. al. Journal of Pediatrics [60], (2011)
The use of constructive conflict tactics (problem solving, displaying affection, etc.) can have positive effects on children, helping them to develop effective ways of problem solving and dealing with conflict and reducing the chance of behavior problems.

Depression was associated with each of the forms of bullying. For physical, verbal, and relational bullies, the frequentlyinvolved group, victims and bully victims, reported a significantly higher level of depression than the corresponding occasionally involved group. For cyber bullying, differences were found only between the occasional and frequent victims.

Living with fathers with depressive symptoms and other mental health problems is independently associated with increased rates of emotional or behavioral problems of children. 
Aravind, VK \& Krishnaram, VD [14] (2010)

Mennella et. al. [127] (2010)

Uddin M et. al. [181] (2010)

Briggs-Gowan,

M. J. et. al. [112] (2010)

DeGarmo DS et al.. [268] (2010)

Joormann et. al.

[61] (2010)

Greenfield, E. A.

\& Marks, N. F.

[111] (2010)
Child Maltreatment

Indian Journal of Psychological

Medicine

Addiction

Addiction

Depression and Anxiety

Psychiatry

American Journal of Men's

Health

Journal of Child Psychology and Psychiatry

Child Abuse \& Neglect
Neglected children reported more likely to develop depressive symptoms than comparison children.

Major Depressive Disorder is associated with severe consequences, including deterioration in academic functioning, increased risk of substance use and other mental disorders, and most critically attempted and completed suicides.

The co-occurrence of having a family history of alcoholism and self-reports of depressive symptomatology was associated significantly with a preference for a more concentrated sucrose solution, while depressive symptomatology alone was associated with greater liking for sweet-tasting foods and candies and increased pain sensitivity. Depression antagonized the analgesic properties of sucrose.

In adolescent females, the 5-HTTLPR sl genotype confers protection against depressive symptoms independent of countylevel social context whereas in adolescent males, protection by the same genotype is conferred only within the context of county-level deprivation.

Parents reported elevations in a wide range of symptoms and disorders among 2- and 3-year-old children who had been exposed to potentially traumatic events. As expected, these associations were particularly evident in relation to family violence exposure, which was positively associated with symptoms and disorders of depression, anxiety, and disruptive behavior.

Controlling for fathers' antisociality, negative life events, and social support, fathering identity predicted reductions in healthrelated problems and marijuana use. Father involvement reduced drinking and marijuana use. Antisociality was the strongest risk factor for health and substance use outcomes.

Daughters of depressed mothers required greater intensity than did daughters of control mothers to accurately identify sad facial expressions; they also made significantly more errors identifying angry expressions. Cognitive biases may increase vulnerability for the onset of disorders and should be considered in early intervention and prevention efforts.

Results provide evidence that frequent experiences of psychological violence from parents-even in the absence of physical violence and regardless of whether such violence is from mothers or fathers-can place individuals' long-term mental health at risk. Moreover, frequent physical violence from fathers-even in the absence of psychological violence-also serves as a risk factor for poorer adult mental health. 


\begin{tabular}{|c|c|c|}
\hline Author (Year) & Periodical & Main findings \\
\hline $\begin{array}{l}\text { Gotlib, I. H. et. al. } \\
\text { [148] (2010) }\end{array}$ & Archives of General Psychiatry & $\begin{array}{l}\text { Familial risk for depression affects neural mechanisms underlying the processing of reward and loss; young girls at risk for } \\
\text { depression exhibit anomalies in the processing of reward and loss prior to the onset of depressive symptoms. }\end{array}$ \\
\hline $\begin{array}{l}\text { Mazefsky, C. A., } \\
\text { Conner, C. M. } \\
\text { \& Oswald, D. P } \\
\text { [149] (2010) }\end{array}$ & Autism Research & $\begin{array}{l}\text { With regard to proband comorbidity, } 32 \% \text { of adolescents with Autism Spectrum Disorders (ASD) met criteria for lifetime } \\
\text { history of a co-morbid depressive disorder and } 39 \% \text { met criteria for lifetime history of an anxiety disorder. Participants } \\
\text { with ASD could be correctly classified as having one of these comorbid conditions or not based on mothers' current mood } \\
\text { symptoms for the majority of cases. }\end{array}$ \\
\hline $\begin{array}{l}\text { Duarte CS et. al.. } \\
\text { [164] (2010) }\end{array}$ & Journal of Pediatrics & $\begin{array}{l}\text { Our results indicate that conduct problems in childhood are prospectively associated with both being overweight and obesity } \\
\text { in early adulthood in male subjects in Finland. }\end{array}$ \\
\hline $\begin{array}{l}\text { Wojnar J et. al.. } \\
\text { [169] (2010) }\end{array}$ & Sleep Medicine & $\begin{array}{l}\text { These findings suggest that children and adolescents with Major Depressive Disorder and a high Body Mass Index have more } \\
\text { fragmented sleep than other children. The increased Rapid Eye Movement sleep patterns observed with MDD in this and } \\
\text { other studies normalized in high-weight children with MDD. }\end{array}$ \\
\hline $\begin{array}{l}\text { Keenan K et. al.. } \\
\text { [173] (2010) }\end{array}$ & Journal of Adolescent Health & $\begin{array}{l}\text { The interaction of low levels of assertiveness and high peer victimization at age } 9 \text { was predictive of depression symptoms at } \\
\text { age 11, controlling for earlier depression symptoms. }\end{array}$ \\
\hline $\begin{array}{l}\text { Wingo et. al.. } \\
\text { [219] (2010) }\end{array}$ & Journal of Affective Disorders & $\begin{array}{l}\text { Resilience moderates depressive symptom severity in individuals exposed to childhood abuse or other traumas both as a main } \\
\text { effect and an interaction with trauma exposure. Resilience may be amenable to external manipulation and could present a } \\
\text { potential focus for treatments and interventions. }\end{array}$ \\
\hline $\begin{array}{l}\text { Nakonezny et. al.. } \\
\quad \text { [231] (2010) }\end{array}$ & $\begin{array}{l}\text { Journal of Child and Adolescent } \\
\text { Psychopharmacology }\end{array}$ & $\begin{array}{l}\text { The results suggest that, with Electronic Monitoring as the reference standard, the 12-week mean estimate of EM medication } \\
\text { adherence for the sample of depressed youth is high (87.5\%). }\end{array}$ \\
\hline $\begin{array}{l}\text { Tao et. al.. [232] } \\
\quad(2010)\end{array}$ & $\begin{array}{l}\text { Journal of Child and Adolescent } \\
\text { Psychopharmacology }\end{array}$ & $\begin{array}{l}\text { The current study indicates that all depressive symptoms improve over the } 12 \text { weeks of acute antidepressant treatment, } \\
\text { with the largest improvement occurring during the first } 4 \text { weeks of treatment. Two symptom factors, Morbid Thoughts and } \\
\text { Observed Depressed Mood, were rated low at baseline, but did show improvement over the course of treatment. }\end{array}$ \\
\hline $\begin{array}{l}\text { Kohrt et. al.. [242] } \\
\qquad(2010)\end{array}$ & BMC Psychiatry & $\begin{array}{l}\text { The potential pitfalls of assuming that only translation and back-translation can capture cultural differences in performance of } \\
\text { mental health instruments. While the specific process of transcultural translation and validation will vary based on objectives } \\
\text { and local resources, a critical evaluation of the translation and validation process is indispensible. }\end{array}$ \\
\hline
\end{tabular}




\section{Author (Year)}

Stone LB, Uhrlass

DJ, Gibb BE. [262]

$$
\text { (2010) }
$$

Chen et. al., [118] (2010)

Frodl et. al., [122] Neuropsychopharmacology (2010)

In-Albon et. al., Swiss Medical Weekly [183] (2010)

Middeldorp et. al., [15] (2010)

Ogburn et.al., [48] (2010)

Olvera et. al. [134] (2010)

Silberg et. al., [69] (2010)

Van Oort et .al., [56] (2010)

\section{Periodical}

Journal of Clinical Child \&

Adolescent Psychology

Archives of General Psychiatry

Genes, Brain and Behavior

Psychopathology

Psychiatry Research

Journal of Child Psychology and Psychiatry

European Child \& Adolescent Psychiatry

\section{Main findings}

The results of this study, therefore, suggest that co-rumination is not merely a correlate of ongoing depression. That is, current levels of co-rumination were related to children's past history of depressive diagnoses among children who were not currently depressed.

Voxel-based morphometry analyses indicated that individuals at high risk of depression had significantly less gray matter density in clusters in the bilateral hippocampus than low-risk participants. Tracing yielded a volumetric reduction in the left hippocampus in the high-risk participants.

The transmission of depression symptoms is due in part to environmental processes independent of inherited effects and is not accounted for by shared adversity measurements. Girls may be more sensitive to the negative effects of maternal depression symptoms than boys through environmental processes.

Pediatricians estimated that 15\% percent of children in their pediatric setting reported psychological difficulties. Of these, childhood depression is one of the most frequent mental disorders among children, they have the important role in recognizing the early signs of mental problems.

This longitudinal study in children and adults found no association of single nucleotide polymorphisms in the serotonergic system or core regulators of neurogenesis with Anxiety and Depression.

The families with major depressive disorder children showed higher levels of conflict and lower levels of cohesion ( $p<0.001)$, expressiveness and active-recreational orientation compared to the families without mentally ill children.

This study found significantly lower levels of NAA (N-acetil-aspartase) in the right medial prefrontal cortex and significantly lower levels of NAA and GPC + PC (glycerolphosphocholine plus phosphocholine) in the right AC(anterior cingulate) of depressed children and adolescents compared with healthy control subjects.

Both the family environment as genetic factors are responsible for association between parental depression and onset of depressive symptoms in children. However, the environment factor was more significant.

The parenting stress was another risk factor for symptoms of depression in children both in the present, as a risk factor to onset of depressive symptoms on the future. 


\section{Discussion}

\section{Etiology/Risk Factors}

\section{Social and Environmental Factors}

Reflecting through ideas of MidDeldorp et. al [15] the etiology of depression and anxiety has been extensively investigated in recent years. Given the accumulating evidence about the high prevalence and debilitating related to childhood depression, a better understanding of the etiology of depression in youth is needed $[16,17]$

Several investigations have demonstrated a wide variation in the prevalence of depression in children and differences according to the criteria of diagnostic classification adopted, mainly due to the diverse mode of presentation of depression and the association of this disorder with other psychopathologies [18]. Prevalence estimates among different racial/ethnic groups vary widely too [19]: American Indian youths reported the highest prevalence of depressive symptoms (29\%), followed by Hispanic (22\%), non-Hispanic White (18\%), Asian American (17\%), and African American (15\%) youths $[19,20]$. Thus, knowing the risk factors for depression during childhood is essential for a better understanding of the etiology of this disorder and for planning prevention strategies [18].

Major Depressive Disorder (Single or Recurrent) is twice as common in adolescent and adult females as in adolescent and adult males. In prepubertal children, boys and girls are equally affected [21]. Studies of Major Depressive Disorder have reported a wide range of values for the proportion of the adult population with the disorder. The lifetime risk for Major Depressive Disorder in community samples has varied from $10 \%$ to $25 \%$ for women and from $5 \%$ to $12 \%$ for men. The point prevalence of Major Depressive Disorder in adults in community samples has varied from $5 \%$ to $9 \%$ for women and from $2 \%$ to $3 \%$ for men [21].

In this context, studies addressing the etiology and risk factors of childhood depression emphasize some important points, among them are individual, environmental and family factors. Individual factors include age, gender, psychological and physical vulnerability [8, 22], comorbidity with other disorders $[8,23]$, emotional disturbance, impaired sociability, low self-esteem and social skill difficulties [8, 24, 25], according to Table $2[8,22]$.

Family factors associated with childhood depression vulnerabilities consist of child abuse and marital conflict [8, 26, 27]; parental depression [8, 28]; rejection and low interaction with the child [8, 29]; losses related to separation and death $[8,30]$ and a history of insecure attachment [8, 31, 32]. Lastly, environmental factors include daily difficulties, stressful or traumatic life events [8,33, 34], lack of social support and poor friendships [8, 12, 27-34].

It's well established that secondhand smoke (SHS) exposure causes adverse physical health conditions (eg, respiratory and cardiovascular) [35-38], and there is increasing evidence suggesting that it may also adversely affect mental health [35]. SHS may be a proxy for stressful living conditions, and stress has been associated with poor mental health [35, $39,40]$. In response to stress, the hypothalamicpituitary-adrenal axis and immune, metabolic, autonomic, and cardiovascular systems respond to keep the environment of the body in homeostasis [35, 41]. Although chronic physical conditions usually manifest in adulthood, there is evidence that prolonged exposure to stress may have an effect on the response of the body to stress and result in poor health even among children [35, 42-44]. Other hypotheses suggest a link between smoking and poor mental health through nicotine and dopamine pathways [35, 45-47].

The study of BANDiERA et. al. [35] was the first study to assess the association between biologically confirmed SHS exposure and mental disorder symptoms in a nationally representative sample of US children and adolescents. In this study, it was proved that SHS exposure was positively associated with symptoms of Major Depressive Disorder, 
Table 2. Baseline Demographic and Clinical Characteristics by Diagnosis. [8, 22].

\begin{tabular}{|c|c|c|c|c|c|}
\hline & $\begin{array}{l}\text { Control } \\
(n=32)\end{array}$ & $\begin{array}{l}\text { High Risk } \\
(n=22)\end{array}$ & $\begin{array}{l}\text { Depressed } \\
(n=29)\end{array}$ & Statistic & p \\
\hline Age (Years) & $15.1(1.6)$ & $15.0(1.7)$ & $14.6(1.9)$ & .65 & NS \\
\hline \multicolumn{4}{|l|}{ Sex } & 4.09 & NS \\
\hline Male & $19(59.4)$ & $13(54.5)$ & $10(34.1)$ & & \\
\hline Female & $13(40.6)$ & $9(45.5)$ & $19(65.5)$ & & \\
\hline \multicolumn{4}{|l|}{ Ethnicity } & .30 & NS \\
\hline Caucasian & $15(46.9)$ & $9(40.9)$ & $14(48.3)$ & & \\
\hline Non-Caucasian & $17(53.1)$ & $13(59.1)$ & $15(51.7)$ & & \\
\hline \multicolumn{4}{|l|}{ Pubertal Status } & .03 & NS \\
\hline Tanner Stage III & $4(12.5)$ & $3(13.6)$ & $4(13.8)$ & & \\
\hline Tanner Stage IV & $10(31.3)$ & $7(31.8)$ & $9(31.0)$ & & \\
\hline Tanner StageV & $18(56.3)$ & $12(54.5)$ & $16(55.2)$ & & \\
\hline Socioeconomic Status ${ }^{1}$ & $47.4(8.5)^{a}$ & $40.2(10.9)^{b}$ & $38.1(9.8)^{b}$ & 6.81 & .002 \\
\hline Beck Depression Inventory & $1.6(2.2)^{a}$ & $3.1(2.8)^{\mathrm{a}}$ & $14.3(8.9)^{b}$ & 39.11 & .0001 \\
\hline Hamilton Depression Scale & $1.2(1.7)^{\mathrm{a}}$ & $1.6(2.7)^{\mathrm{a}}$ & $20.0(5.5)^{b}$ & 227.90 & .0001 \\
\hline CGAS Score1 & $85.0(8.9)^{\mathrm{a}}$ & $74.9(10.2)^{b}$ & $57.0(12.4)^{c}$ & 36.32 & .0001 \\
\hline Early-Life Adversity & $9.0(2.2)^{\mathrm{a}}$ & $12.5(3.9)^{b}$ & $11.6(3.8)^{b}$ & 8.46 & .0001 \\
\hline Adolescent Chronic Stress & $17.6(3.2)^{\mathrm{a}}$ & $20.7(3.4)^{b}$ & $22.5(4.6)^{b}$ & 12.61 & .0001 \\
\hline \multicolumn{6}{|c|}{$\begin{array}{r}\text { Data in parenthesis reflect standard deviations or percentages. Different subscripts denote significant differences among } \\
\text { groups }\end{array}$} \\
\hline \multicolumn{2}{|c|}{$\begin{array}{l}1 \text { Higher score is associated with higher socioeconomic } \\
\text { status or higher level of functioning. }\end{array}$} & \multicolumn{4}{|c|}{$\begin{array}{l}\text { CGAS: Children's Global Assessment Scale; } \\
\text { NS: Not Significant. }\end{array}$} \\
\hline \multicolumn{2}{|c|}{$\begin{array}{l}\text { A Data in parentheses reflect standard deviations or } \\
\text { percentages. }\end{array}$} & \multicolumn{4}{|c|}{$\begin{array}{l}\text { B Different subscripts denote significant differences among } \\
\text { groups. }\end{array}$} \\
\hline
\end{tabular}

Generalized Anxiety Disorder, Attention Deficit and Hyperactivity Disorders, and conduct disorder.

\section{Family and Hereditary Factors}

A careful attitude is strengthened when considering the family environment may represent a critical early contribution to the risk for mood disorders [4850]. Children exposed to chronic adversities early in life are more likely than other children to suffer a variety of mental health problems, as depression [51-55]. According to VAN OORT et. al. [56] the parenting stress was another risk factor to depressive symptoms in children. That said, children of parents with depressive disorders are a high risk group for developing depressive episodes [57-61]. They have two to three times more likely to show high levels of depression and symptoms of anxiety and depression than children of non-depressed parents [62, 63]. It has been well established in recent studies that a family history of depression is an important predictor of emotional and behavioral problems in children [64-69] According Silberg et. al. [69] despite the convincing evidence for transmission from parents to children, the mechanism by which parental depression increase the depression risk in children is not well understood. 
WeitZMAn et. al. [60] analyzing a representative sample of US children ( $N=21993$ ) aged 5 to 17 years and their mothers and fathers have found the rates of such problem are lower among children with fathers who have mental health problems than among children with mothers with these problems. They have found too that the rates of emotional or behavioral problems are highest among children who have both mothers and fathers with mental health problems and depressive symptoms, with $25 \%$ of children living in such homes having behavioral or emotional problems.

Researches have shown consistently that children of depressed mothers are at elevated risk for developing a range of psychiatric disorders, as depression [70-72]. This risk persists beyond the duration of a given maternal depressive episode and can continue into adulthood [70, 73]. Daughters may be especially vulnerable; investigators have found that daughters of depressed mothers are more likely to develop Psychopathology than are son [70, 74, 75].

Lewis et al. [62] yet seek to explain this transmission of depression from parents to the children. First, exposure to parent depression symptoms may have a direct environmental effect on children. Second, links between parent and child symptoms could arise through inherited factors. Researchers $[76,77]$ explain that genes play an important role in explaining the appearance, behavior and personality characteristics of people. Therefore, genes involved in negative mood of the parents are involved in depression in adolescents and children. Also, shared exposure to adversities such as bereavement, divorce, or poverty may increase risk for depression in parents and children, accounting for observed transmission effects [62].

A consistent finding from twin research has been that genetic influences on depression symptoms are greater in adolescents, whereas shared environment is more influential in children $[62,78]$. This suggests that non-inherited factors could play a more prominent role in the intergenerational transmission of depression symptoms for younger children [62]. Also, there are findings suggesting that approximately $1 / 5$ of the additive genetic influences on both Conduct Disorder and Major Depressive Disorder are shared between the two phenotypes in boys, but this is entirely accounted for by genetic influences on Negative Emotionality [79].

However, further research on the mechanisms underlying intergenerational transmission of depression is required. In addition to the role of shared adversity, such research should consider the effects of child gender and age, which have not been examined using genetically sensitive designs. As already mentioned, there is evidence that different factors may be involved in the etiology and intergenerational transmission of depression for boys and girls [70]. Some studies found that the association between maternal depression and offspring is stronger in daughters than sons [70, 74, 75]. However, other studies have not reported gender differences [62, 80]. The etiology of depressed child can range according children's development stage too [62].

A better understanding of the pathways involved in the intergenerational transmission can help identify modifiable risk factors for the child/adolescent with depressive symptoms that could be the target of preventive and therapeutic interventions. The results of SILBERG et al. [69] still implicate a different etiologic role of parental depression depending upon the age of the child. Early in childhood, the effect of the parental depression is environmental. As children approach adulthood, the association between parental and child depression appears to be primarily genetic.

Sexual abuse experiences in childhood confer high risk for developing clinical depression and possible mechanisms by which they play their deleterious effect [81]. Studies point out that a history of childhood sexual abuse is associated with increased risk of major depressive disorder associated with suicidal thoughts and behavior, including suicidal thoughts, persistent suicidal thoughts, suicide plan and at- 
tempt. The researchers also reported risks associated to Psychopathology, include, but not limited to the major depressive disorder [82].

The study of BeNNETT et al. [83] demarcate the relation of the onset of depression in neglected children. Neglected children reported more likely to develop depressive symptoms than comparison children. Neglect often occurs in the presence of other psychosocial risk factors, such as low socioeconomic status (SES) and exposure to violence [83-85]. Low SES and exposure to violence have each been associated with increased depressive symptoms in childhood [83, 86, 87]. Specifically, children who experience neglect may be at increased risk of experiencing shame, which in turn increases their risk for depressive symptoms [83]. Shame is a highly negative and painful state in which the individual perceives the whole self as defective $[83,88]$. Heterogeneous groups of maltreated children, which have included neglected as well as physically and sexually abused children, exhibit elevated levels of shame [83, 89-91]. Similarly, children whose parents are negative and rejecting or who use an authoritarian style of parenting are at increased risk of exhibiting shame [83, 89, 92-94].

There are several explanations as to how shame, which has been related to increased depressive symptoms in children among neglected children [83, 94-96]. When experiencing shame, individuals may try to suppress such an aversive feeling. Shame suppression, in turn, may lead to sadness and depression [83, 97, 98]. Alternatively, shame, which is characterized by a desire to hide the damaged self from others and to "disappear," may be associated with social isolation [83, 98-100]. Shame also is associated with a depressogenic attributional style that may increase risk for developing depressive symptoms [83, 101-103]. Finally, shame has been related to increased pro-inflammatory cytokine activity and to cortisol changes, both of which may increase risk for depressive symptoms [83, 104, 105]. Although the precise mechanisms by which shame may lead to the development of depressive symptoms is currently unknown, the extent to which neglected children are prone to experience shame may also lead them to experience increased depressive symptoms [83].

Fear of abandonment has been found, associated with mental health problems for youth who have experienced a parent's death [106]. The parental death in childhood is associated with an increased risk for depression [106-108]. Disorganization and depression after bereavement are lessened only when an individual's regulatory system is able to adapt in another close relationship [106].

Children exposed to high levels of maternal repeated criticisms are subject to greater risk of developing depression. It is evident a potential modifiable risk factor for depression in childhood: repeated exposure to maternal criticism [17]. The societal pressure and social sanctions that result against even minor conduct problems may heighten girls' risk for subsequent depression [109, 110]. In this context, family violence generally increases the risk of depression for children [111]. In older children, exposure to family violence has been linked to internalizing problems (eg, depression, suicide, anxiety, post-traumatic stress) [112-114].

The pathogenic influence of stressors in childhood, particularly maltreatment, increases risk for depression [115-117]. Indeed, severe stressors, such as childhood abuse and others already cited, have been postulated to lead to reduced hippocampal volume in adulthood and may represent a link between hippocampal volume and Psychopathology [118-121]. Results of FrodL et al., [122] indicate that subjects with both environmental and genetic risk factors are susceptible to stress-related hippocampal changes. In systemic inflammation, pro-inflammatory cytokines have been implicated in altering activity in brain regions known to affect emotion processing and emotion regulation in depression [123]. Structural brain changes due to stress represent part of the mechanism by which the illness 
risk and outcome might be genetically mediated [122].

It is noteworthy, however, not all individuals exposed to childhood adversity develop depression, and genotype may moderate the relationship between childhood adversity and mental health [115, 124, 125]. This fact shows that the etiology of depressive disorders is complex and multi-factorial, with an intricate interaction among environmental factors and genetic predisposition [126].

In the study of MenneLLa et al. [127], was revealed for the first time that in pediatric populations the co-occurrence of having a family history of alcoholism and self-reports of depressive symptomatology is associated significantly with preference for stronger sweet solutions. (Figure 2)

\section{Neurochemical factors}

The underlying neurobiology of depression is likely to represent an interaction between genetic susceptibility and environmental factors such as stress [122]. There are two major hypotheses regarding the etiology of anxiety and depression: the monoamine hypothesis and the hypothesis of an abnormal stress response acting partly via reduced neurogenesis. Forty-five SNPs were assessed in candidate genes that were involved in (1) the mono-aminergic system: serotonin receptors (HTR) 1A, 1D, 2A, catechol-O-methyltransferase (COMT), tryptophane hydroxylase type 2 (TPH2), (2) neurogenesis: brain derived neurotrophic factor (BDNF) and PlexinA2 and (3) cell signaling: regulators of $\mathrm{G}$-protein signaling (RGS 2, 4, 16) [15].

For several reasons, researchers have focused on the role of the hippocampus in depression [118]. The hippocampus is involved in the regulation of the hypothalamic-pituitary-adrenal (HPA) axis, which is responsible for production of stress-related glucocorticoids such as cortisol [118, 128]. In this context, depressed individuals have consistently been found to report high levels of stress [118, 129], which is reflected biologically in elevated rates of hypercortisolemia $[118,130]$ and disturbed HPA-axis functioning [118, 131].

Figure 2: How to explain the transmission of depression from parents to the children

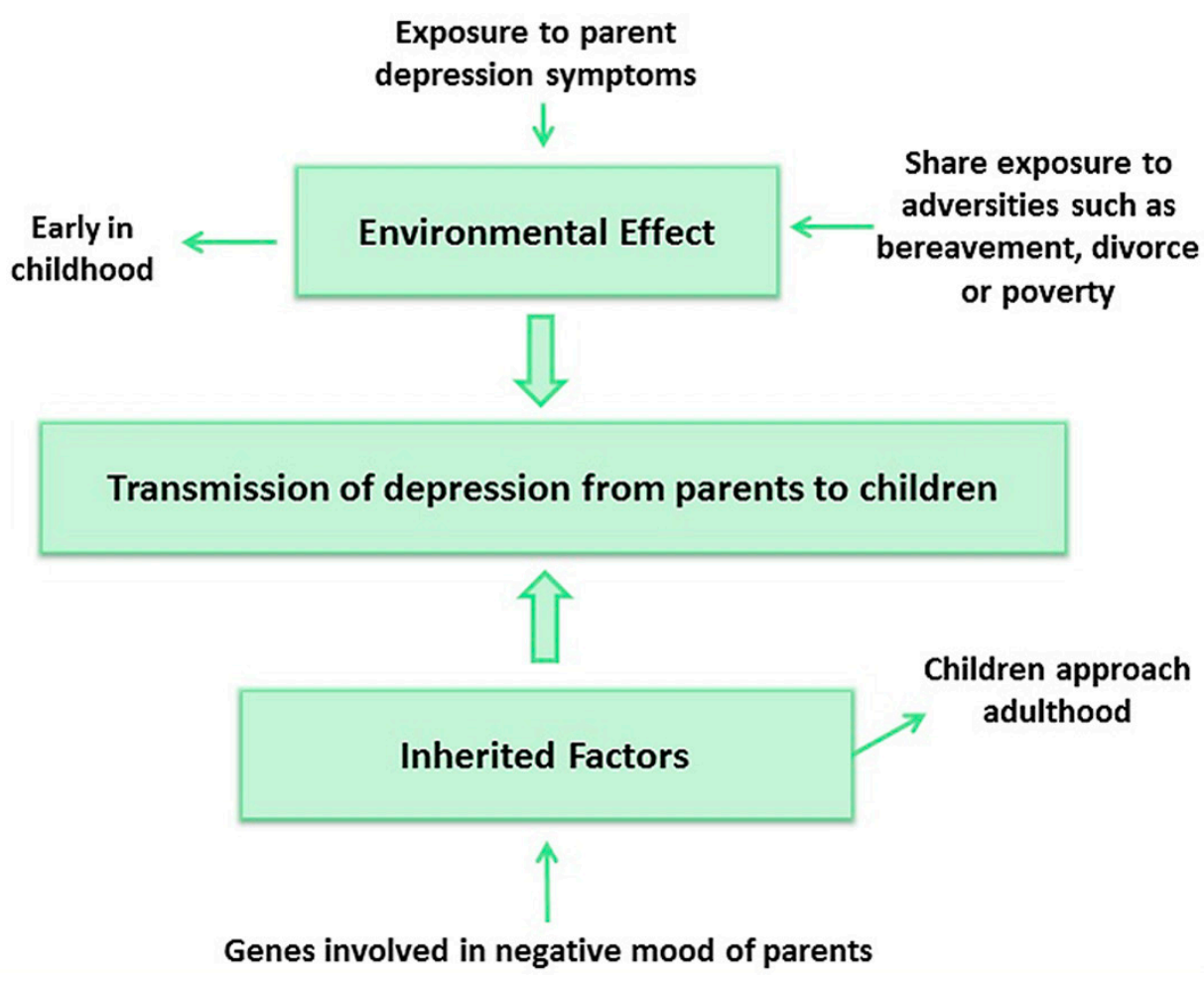


BENKO et al., [126] in a study with children aged between 9-12 years old have found a strong association between depressive symptoms and caffeine consumption. Previous studies have also suggested that the early consumption of caffeine can be an indication of later drug abuse [126]. The children with sleep problems were at risk for depression symptoms [132]. The question that remains unknown is whether high caffeine consumption may actually cause symptoms of depression or ease the symptoms of depression in children which already presented them, once studies have also shown that adults often use substances, as caffeine, to alleviate psychiatric symptoms [126, 133].

\section{Anatomopathological factors}

With advances in neuroimaging techniques, investigators have been able to examine the function and structure of specific brain regions in this disorder [118]. Numerous magnetic resonance imaging (MRI) studies show volumetric reductions in the frontal cortex and its sub regions in adults with major depressive disorder (MDD) [134-139]. The few MRI studies done in children and adolescents with MDD, also suggest evidence of frontal lobe involvement [134]. Decreased frontal volume and increased ventricular size were seen in depressed children compared with psychiatric controls [134, 140]. Another study found smaller left-sided prefrontal cortex (PFC) gray matter volumes in patients with familial MDD than in patients without a family history of MDD [133, 141]. Furthermore, subjects without a family history of MDD had larger left sided total PFC volumes and PFC white matter volumes compared with patients with familial MDD [133, 141].

Neuroimaging studies have shown that the hippocampus is about 4-5\% smaller in patients with major depression than in healthy controls, and that reduced hippocampal volumes are consistently found in major depression [122, 142-144]. Pediatric patients with familial MDD showed decreased hippocampal volumes, indicating that reduced hippocampal volume may be present at very early stages and may be suggestive of a risk factor for developing MDD $[122,145]$.

Moreover, depressed patients have also been found to be characterized by difficulties in hippocampal-dependent learning and memory [118, 146]. These factors, in addition to the high degree of connectivity between the hippocampus and other brain regions critical for emotion and cognition make this structure a prime candidate for further investigation [118, 147].

Researchers have found decreased hippocampal [122, 145], prefrontal cortex, orbitofrontal cortex, gyrus cinguli, and the basal ganglia volumes in patients with MDD compared with healthy controls $[122,143]$.

The study of GotLiB et al. [148] has also documented a prominent role of the insula as an index of normal and disordered reward functioning; this structure may be a promising candidate for a biological marker of risk for the development of a depressive disorder.

\section{Comorbidities}

Both depression [149, 150] and anxiety [149, 151] have each been described as the most common psychiatric concern for children with autism spectrum disorder (ASD) [149]. The child's disability and the tension in the family are some factors that justify it [149]. Studies report prevalence rates in the range of $4 \%$ to $57 \%[149,150,152]$ and from $7 \%$ to $84 \%$ $[149,151,152]$ for depression and anxiety disorders in children with ASD [149].

Several studies [153-160] in adults have shown that patients with syncope exhibit high levels of psychological distress, including anxiety and depression. HyPHANTIS et al. [153] reported an incidence of 35\% in clinically significant depressive symptoms in children and adolescents with Neurocardiogenic Syncope, a 2.6-fold higher rate compared with healthy control subjects. Family functioning, as indicated by 
child-parent relationships and family cohesion, was associated with depressive symptomatology.

Children with cancer are also likely to develop some type of depressive disorder. Conflicts arising from cancer such as problems in daily life, increased frequency of visits to the hospital and poor quality of life in children were correlated to an increase in the child's tendency to suffer depression [162].

Depression is an important health problem in children and the onset of depression is occurring at a younger age than previously suggested [162]. The associations of being overweight and low socioeconomic status in childhood depression have been well documented [162]. Children in families of low socioeconomic status that experience family disruption or parental divorce, or that have a history of mental disorders may be at an increased risk of developing depression in later life [87, 162, 163].

Some studies reported the relationship between depression and obesity in boys and girls [164, 165], whereas other studies reported the relationship in girls only $[164,166,167]$. Other studies found that boys with chronic obesity are more likely to be depressed [164, 168].

According to the study of WoJnAR et al., [169] sleep disturbances also increase the risk for developing depression across the life cycle [169-172]. High-weight depressed children would have worse sleep than both normal-weight depressed children and healthy control children [169]. Since poor sleep already poses a greater risk of relapse and recurrence of depression, then increasing body mass index (BMI) may further increase that risk [169].

The study of BANH et al., [19] have sought to analyze the ethnic influence in depression. Their findings suggested that the MFQ (Mood and Feelings Questionnaire) demonstrates sufficient measurement equivalence for $6^{\text {th }}$ or $8^{\text {th }}$ graders, males and females, youth with US- and non-US born parents. In general, their findings suggested that although there may be differences in symptom endorsements among depressed individuals across racial/ethnic groups, these differences do not impact overall scores MFQ in children with depressive symptoms.

Being a victim of negative peer experiences is significantly associated with depression [173, 174], especially for girls $[173,175]$. Studies have consistently shown that depression is associated with exposure to bullying $[176,177]$. The study of WANG et al [176] examined associations between depression and four forms of bullying: three traditional (physical, verbal, and relational) and the fourth a relatively new form (cyber). For traditional bullying, the associations between depression and frequency of involvement within bullies, victims, and bully-victims were consistent with previous studies [176, 178]. In contrast, for cyber bullying these associations were not found for bullies or bully-victims. Notably, cyber victims reported higher depression than bullies or bully-victims, which was not found in any other form of bullying. This may be explained by some distinct characteristics of cyber bullying [176, 179]. For example, unlike traditional victims, cyber victims may experience an anonymous attacker who instantly disperses fabricated photos throughout a large social network; as such, cyber victims may be more likely to feel isolated, dehumanized, or helpless at the time of the attack [176, 179].

The results of the UHER et al. [180] research affirm that statistical tests of gene-environment interactions showed positive results for persistent depression but not single-episode depression. Individuals with two short 5-HTTLPR alleles and childhood maltreatment had elevated risk of persistent but not single-episode depression.

The study of UDDIN et al [181] highlights that in adolescent females, the 5-HTTLPR sl genotype confers protection against depressive symptoms independent of county-level social context, whereas in adolescent males, protection by the same genotype is conferred only within the context of county-level deprivation. 
Moreover, individuals carrying the 5HTTLPR short (risk) allele or BDNF Met allele had smaller hippocampal or amygdala volumes, or both, when they had a history of childhood maltreatment compared with those who had only one risk factor (environmental or genetic). Independent of genetic risk, childhood stress predicted additional hippocampal white matter alterations [1, 122, 181]. (Figure 3)

\section{Diagnosis}

Pediatricians estimated that 15\% percent of children in their pediatric setting reported psychological difficulties. Of these, childhood depression is one of the most frequent mental disorders among children. Thus, the pediatricians, who are often in contact with children, have the important role in recognizing the early signs of mental problems in pediatric patients [183].

Depression in children younger than 12 years of age is less prevalent than among adolescents; however, it can be reliably diagnosed in children as young as 3 years of age $[183,184]$. The diagnostic criteria for major depressive disorder in adults can be applied to children, with the exception that children can express irritability rather than sad or depressed mood, and weight loss can be seen in terms of failure to achieve the proper weight for the age group. It is worth mentioning that several investigations have demonstrated a wide variation in the prevalence of depression in children and differences according to the criteria of diagnostic classification adopted, mainly due to the diverse mode of presentation of depression and the association of this disorder with other psychopathologies [18]. This happens because the current diagnostic criteria were developed for the adult population, neglecting many of the developmental differences between children/adolescents and adults [11]. The characteristics of symptoms in children vary widely than in adults [14]. So the difficulties in diagnosing depression in children and adolescents are higher than those found in older individuals [11].

Figure 3: Anatomopathological factors and comorbities related with depressed children.

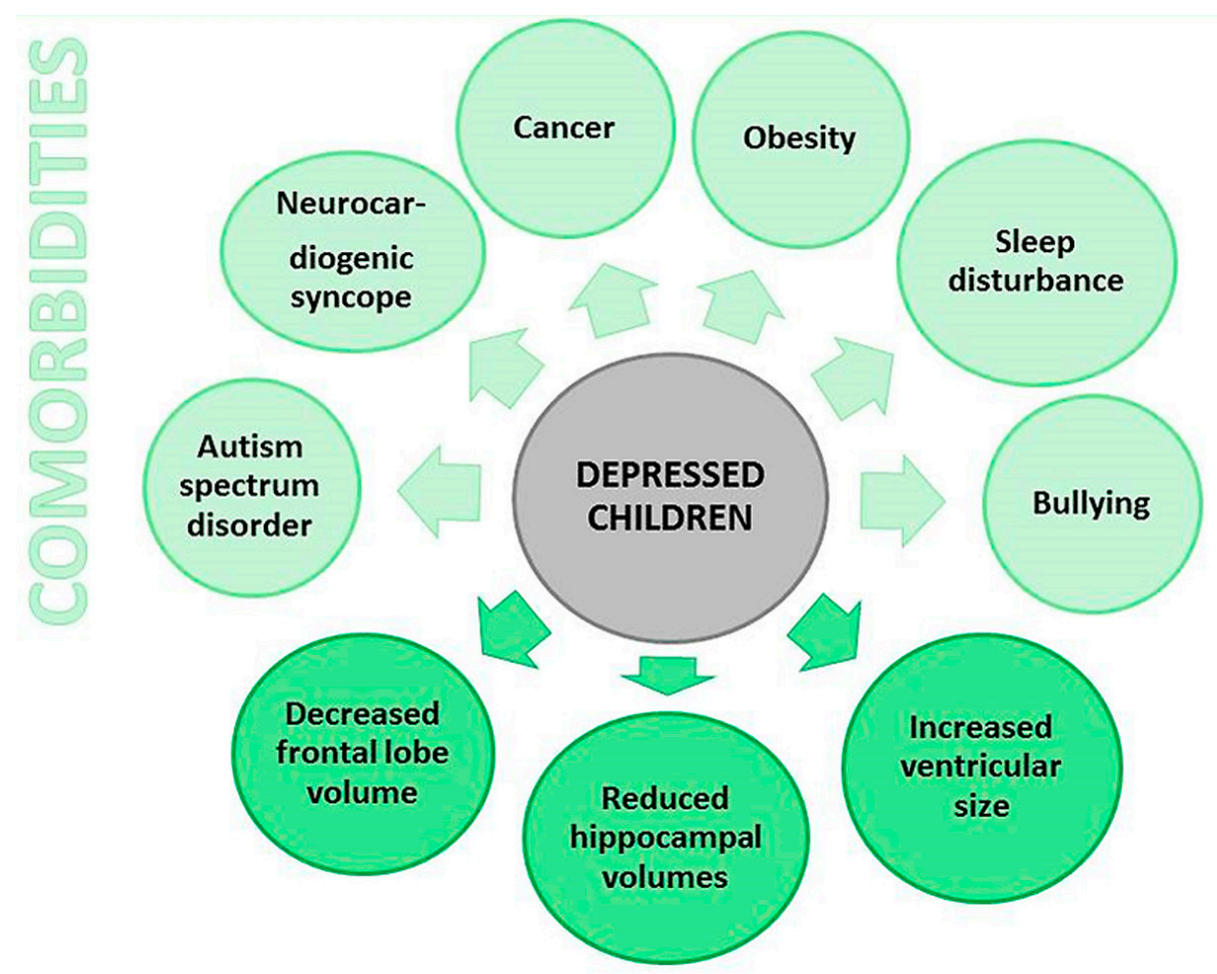

ANATOMOPATHOLOGICAL FACTORS 
Figure 4: Diagnosis methods for child depression.

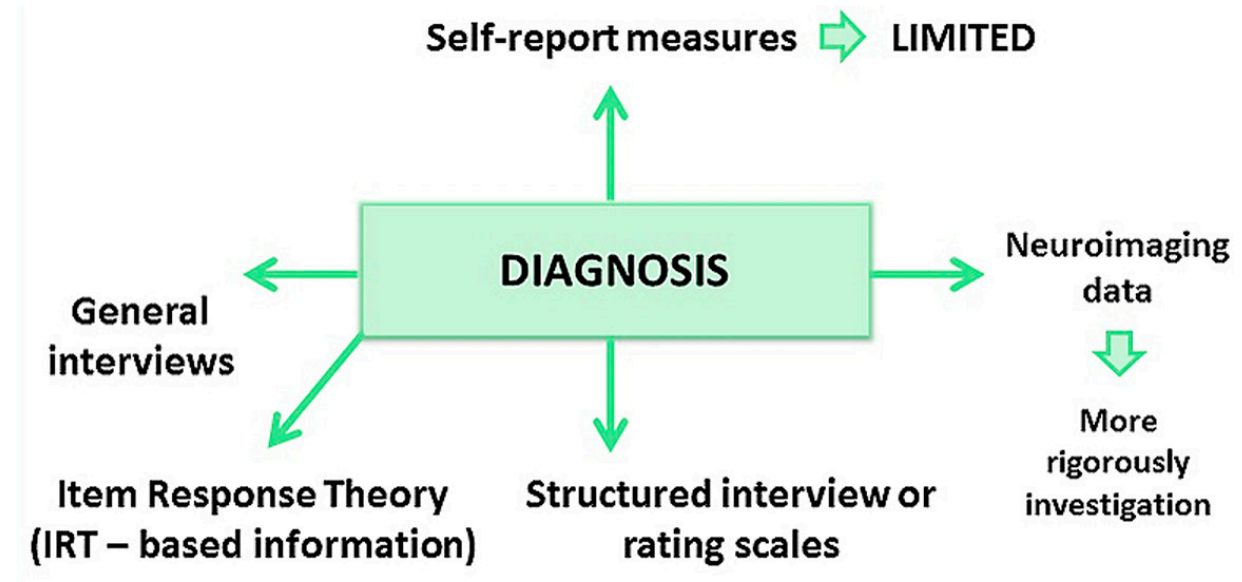

Gives for each symptom a certain level of severity

Traditionally, self-report measures have been the dominant method for assessing internalizing disorders in youth [186-188] as they provide an efficient and cost-effective means of gathering information [188], nevertheless this method has some limitations.

The diagnostic assessment of depressive disorders can make use of formal procedures such as structured/semi-structured interviews or rating scales, in addition to general interviews to assess mental disorders in childhood and adolescence [11]. Neuroimaging data can be another tool in the diagnosis, because it provides a critical area of investigation to more rigorously test the validity of preschool depression [189].

The results of the study of CoLE et al. [190] have also shown that the use of IRT-based information (Item Response Theory) about symptom severity and discriminability in the measurement of depression severity may reduce measurement error and increase measurement fidelity. Some symptoms may be evident at relatively mild levels of the disorder, whereas other symptoms may only emerge at very severe levels. In other words, severe depression may be characterized by symptoms that are not often evident in mild depression. If the severity of depression is assessed simply by counting the number of symptoms, then all symptoms are treated as though they were of equal severity or importance and other valuable information that could be derived from the assessment process potentially is ignored. To avoid this error in the assessment of severity, the IRT gives for each symptom a certain level of severity of depression. (Figure 4)

The importance of the work of these professionals is shown even greater due to the fact that many parents are late in recognizing depression in their children, in spite of obvious Science. These parents may not realize the magnitude of depression until their child's adaptive behavior at home and school has seriously deteriorated, until the child has expressed his desire in the form suicidal or other self-destructive behaviors, or until the child has fallen victim of a devastating drug abuse problem [14].

It is assumed that clinical depression starts as a response to some initiating stress event or process, which elicits sadness, distress, and dysphoria. From thereon, whether or not the dysphoric emotion develops into a disorder depends in large measure on the way in which the affected youngster responds to the emotion [191].

The common feature is the presence of sadness, emptiness, or irritability, accompanied by somatic 
and cognitive changes that significantly affect the individual's ability to function [192].

Depressive symptoms include cognitive and vegetative features in addition to affective features [193]. Patients with depression present with psychological symptoms of depressed mood, loss of interest in activities, impaired concentration, feelings of worthlessness or guilt, and suicidal ideation [194]. Children may have difficulty verbalizing their feelings or may even deny that they are depressed [11]. Thus, special attention should be given to observable manifestations, such as changes in sleep patterns, irritability, poor academic performance, and social withdrawal $[11,195]$. Excessive sleepiness during the day was also observed in children with depressive disorders [196]. It is recognized in some studies that depressive disorders increase the risk of suicidal behavior. They are often associated with morbidities, such as conduct disorder and substance abuse and anxiety disorders. Younger children are more likely to have somatic symptoms, restlessness, separation anxiety, phobias, and hallucinations $[2,197]$. However, little is known as to whether children with a history of very early occurring depression also show altered functional brain responses to negative affective stimuli [198]. It is known also that parents are more likely to indicate externalized symptoms such as irritability, whereas children are more likely to report internalized symptoms such as depressed mood $[2,199]$.

Interpersonal dysfunction has also been linked to the course of depression, such that levels of social support and interpersonal impairment predict depression severity, rate of recovery from a depressive episode, and depression recurrence [200-202]. Regular observation of child development is a good basis for judgment of the problems presented the child: as normal, or as a state or behavior that may require treatment. At the same time, the identification and especially the treatment of mental disorders requires specific knowledge and strategies that are usually not included in pediatricians' training [183].
Thus, the clinician has to look for the cardinal symptoms of depression which include the presence of sadness or depression, anhedonia, crying, irritability, emotional withdrawal, hopelessness and associated guilt, sleep disturbances, failure to gain weight, decline in school performances, hyperactivity and associated restlessness, psychotic disturbances in the form of auditory or visual hallucinations [14]. Anhedonia, a core clinical feature of major depressive disorder $[115,203]$, reflects loss of ability to experience pleasure or joy from activities normally considered pleasurable or, alternatively, lack of reactivity to pleasurable stimuli [115]. The anhedonia depression, sometimes referred to as melancholic subtype, has been identified as one of the more severe forms of major depressive disorder [115, 204, 205].

The study of Allen et. al [206] examined depressive symptoms as a mediator of alexithymia and somatization in a sample of healthy children in order to better understand alexithymia-somatization link from a developmental perspective. Results indicated that depression significantly partially mediated this relationship, at least for two facets of alexithymia (difficulty identifying and describing feelings).

Each additional depressive symptom at ages 8-10 is associated with a $50-80 \%$ increase in risk for developing a depressive disorder by age 11-13 [207, 208]. Sleep disturbances are common in depression; if they precede the onset of this disorder, they may be a biological marker of elevated risk for major depressive disorder [209].

The unremitting suicidal ideas or attempts are the important presentation in certain children. The clinician should also take the time to rule out anxiety or depression in the pediatric population with medically unexplained symptoms. Unexplained somatic symptoms can be often considered as an indicative of a neglected depressive disorder [14].

In this way, depressive symptoms can be understood as a continuum, a diagnostic decision is usually necessary to define the need for treatment 
Figure 5: Cardinal symptoms of depression

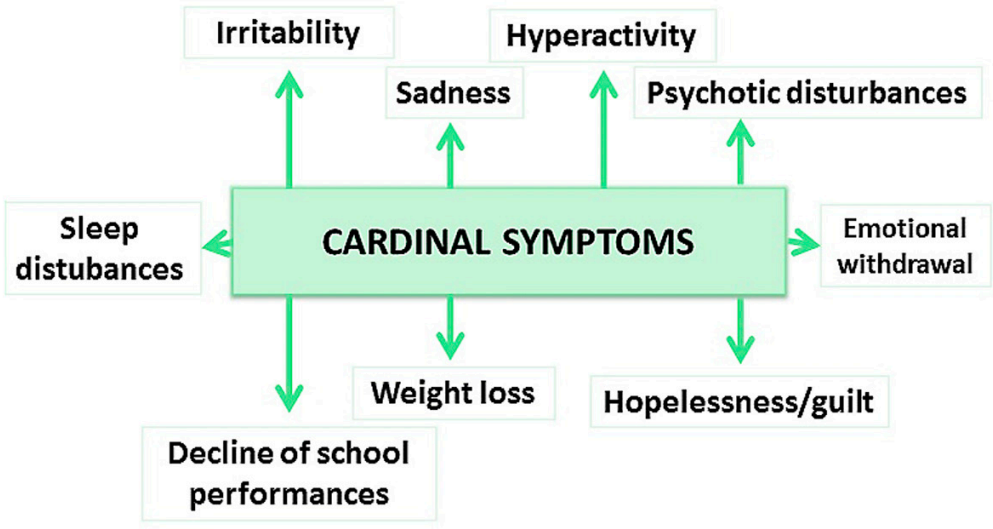

[11]. The identification of depression poses significant clinical challenges to the child psychiatrists. Child depression varies in the nature and intensity of its presenting symptoms. The psychiatrist should attempt to elicit as complete a picture of a child's depressive syndrome as possible by identifying a variety of symptoms associated with this disorder and by estimating their severity [14]. (Figure 5)

\section{Treatment}

The identification and treatment of mood disorders in children and adolescents has grown over the last decades. Major depression is one of the most common and debilitating disorders worldwide, imposing a massive burden to the youth population [11].

Every treatment plan for depression in children and adolescents should take into consideration developmental aspects, including psychoeducation, family support, assessment of comorbid conditions, and risk behaviors [11].

According to ChuA et al. [210] the referral of a child or adolescent with depression to a psychiatrist could be considered in any of the following situations: 1) failure to improve with psychosocial interventions or requiring specialized psychological interventions; 2) failure to improve after at least four weeks of medication treatment at maximum tolerated dose; 3) severe symptoms such as clear suicidal intention, disruptive psychotic symptoms.
According to Kovacs et al. [191] the procedure for the treatment of childhood depression has to have at least four key features. First, the treatment's conceptual formulation (or explanatory framework) should include an explicit developmental component. In other words, the explanatory paradigm should specify which developmental parameters or skills are implicated in the unfolding of depression and how dysfunction in that regard paves the way to depression.

Second, a developmentally informed intervention should accommodate the fact that young patients will be at different stages of development of the targeted skills when they enter treatment, e. g., which will have ramifications for what the therapist can do [191]. The presentation of depressive symptoms can vary according to age groups. Regarding mood changes, younger children show more temporal variability, making harder to characterize a mood episode [11]. Moreover, even in a specific stage of development (children 7 years old), these children will not have the same skill levels and will also differ in the context where they are inserted, which can affect the treatment.

Psychosocial interventions are recommended in initial treatment of depression in children and adolescents based on the literature and local clinical experience [210]. Family-focused interventions also have the advantage of approaching critical issues of the child's context, emerging as a promising 
strategy in recent years, especially in young children $[11,211,212]$. Spending time with caring family members or peers could serve as a protective factor by supporting healthy affective experience and promoting response to treatment [193].

Parental involvement has long been considered indispensable in the treatment of conduct problems. From a psychological perspective, parents play critical roles in their children's emotional and social development and provide the crucible within which developmental skills unfold [191]. A close father-child relationship could provide a unique kind of support for improvement and response to treatment in young people [193]. Additionally, when parents (caregivers) themselves respond to a child's distress, they function as interpersonal regulatory agents [191].

The use of constructive conflict tactics (problem solving, displaying affection, etc. ) can have positive effects on children, helping them to develop effective ways of problem solving and dealing with conflict [212-216] and reducing the chance of behavior problems [213-216]. Conversely, both destructive (aggression, the use of insults, etc. ) and depressive (for example, withdrawal) tactics have been linked with adverse child [214-216].

Relationships with fathers and peers could provide a foundation for treatment outcome, albeit in opposite ways, suggesting that relationships could play a role in treatment response [192].

It is also known that paternal depressive symptoms and other mental health problems are also significantly associated with children's emotional or behavioral problems; this finding raises questions of great importance about how to educate the health care workforce about this, how to develop and implement strategies to facilitate identifying fathers with mental health problems [60].

Prolonged exposure therapy may work primarily by reducing posttraumatic stress, which in turn reduces depression [217].

Depressed children with poor sleep and high body mass index (BMI) may be particularly appro- priate for additional screening and intervention efforts targeted at improving sleep and reducing weight [168].

In relation to children who lost their parents, interventions that reduce the fear of abandonment of children can improve the quality of their social relationships and reduce symptoms of depression later in life. In this context, WINGo et al. [219] emphasized that protective factors such as resilience may be amenable to external manipulation and could present a potential focus for future treatments and interventions.

Affective characteristics such as high positive affect or low negative affect could have relevance for response to treatment in children and adolescents with depression, because these characteristics could indicate a more adaptive pattern of affective style that could promote improvement in response to treatment $[193,220]$. Therefore, according to Kovacs et al. [191], the explanatory paradigm of a developmentally sensitive intervention should address how parents impact the skill that is being targeted or else, account for the role of the parents in those areas of the young patient's functioning that are relevant to treatment targets. Therefore, it is reinforced the importance and the need for research focusing on family interventions and family involvement in the treatment of children with depressive disorders [183].

Pharmacotherapy is recommended for patients with moderate or severe depression [2]. Antidepressants are commonly prescribed to children and adolescents for depression, anxiety, and a variety of other disorder [221, 222]. The efficacy of pharmacologic treatment in pediatric depressive disorders remains unclear, as the majority of placebo-controlled randomized controlled trials (RCTs) of antidepressant medication do not show a significant benefit of medication over placebo [13, 223]. This finding may at least partly explain the low efficacy of antidepressants. The questions about the safety and effectiveness of psychotropic drug use in the pediatric population are widely debated, in particular 
because of the lack of data concerning long term effects [224].

Few psychotropic drugs are licensed for use in children in Europe in general and only for some diseases. Selective serotonin reuptake inhibitors (SSRIs), first introduced in the late 1980s, were prescribed to children for depression on the basis of effectiveness data from trials on adult psychiatric disorders coupled with other trial data demonstrating the ineffectiveness of tricyclic antidepressants [222, 225-228].

Regarding the selective serotonin reuptake inhibitors (SSRIs), a link between its use and an increased risk of suicidal ideation has been documented in the pediatric population and in youth adults [224, 229, 230], a fact that ultimately makes the risk-benefit profile for SSRIs not very favorable. The emergence of suicidal thinking and behavior, or unusual changes in behavior should be monitored during the early phases (generally the first 1-2 months) of antidepressant treatment, especially in children, adolescents and young adults between 18 to 24 years old [210]. Fluoxetine is licensed for major depressive disorder in children over eight years [224] and is the only drug currently licensed to treat depression in children in the United Kingdom as its benefits were deemed greater than its risks [222]. Youth who are adherent to fluoxetine treatment have lower symptom severity over the course of treatment [231].

TAO et al. [232] demonstrated in their study the benefits of therapy with fluoxetine. Their findings emphasize that all depressive symptoms improved, particularly during the first 4 weeks of acute treatment. Forty-seven percent of remitters reported at least one residual symptom following 12 weeks, with most common residual symptoms being impaired school performance, insomnia, and irritability. Residual symptoms are common, even among remitters, at the end of 12 weeks of acute treatment. There is a need for clinicians to monitor symptom improvement and potentially provide additional interventions for the more resistant symptoms, such as insomnia and school performance.
Other antidepressants such as venlafaxine may be considered as second line treatment of depression in children and adolescents [210].

Given that the behavioral effects of many antidepressant depend on neurogenesis in the hippocampus [118, 233] and given that antidepressants treatment prevents stress-related hippocampal volume loss [118, 234] and may reverse hippocampal volume reduction in depression [118, 235], promoting neurogenesis through antidepressants or other interventions in individuals at high risk of depression may prevent or reverse neuronal or glial atrophy and ultimately delay or prevent onset of the disorder [118].

Today, several other classes of antidepressants are being used to treat depression in youths; these are modifications of the earlier antidepressants. Known as "third generation antidepressants", these medications include selective norepinephrine reuptake inhibitors, norepinephrine reuptake inhibitors, norepinephrine dopamine reuptake inhibitors, norepinephrine dopamine disinhibitors, and tetracyclic antidepressants [236, 237]. To date, evidence does not clearly answer questions about the effectiveness and safety of these newer antidepressants [236, 237]; clearly, further research is indicated [237].

In practice the response to treatment in child and adolescent affective disorder is variable, with limited ability of any one treatment to improve outcome across patients [193]. A combination of psychosocial interventions and selective serotonin reuptake inhibitors may be considered for moderate to severe depression in children and adolescents [210]. Unfortunately, we know little about the factors that explain this variability in treatment response. Individual differences in the social and affective dynamics of daily life could help to elucidate the characteristics of youth who respond to treatment [193].

In the pediatric population, evidence suggests the efficacy of pharmacological agents, cognitive behavioral therapy (CBT) or interpersonal therapy (IPT) - all these interventions, however, present only 
intermediate effect sizes in randomized controlled trials [11]. There is increasing recognition of religious involvement as a protective influence that may prevent or assuage the development of depression [238-241].

KonRT et al. [242] emphasize the problem of lack of culturally adapted and validated instruments for child mental health and psychosocial support in low and middle-income countries. This fact causes barriers to assess the prevalence of mental health problems in children from vulnerable populations and/or social risk, evaluating interventions effectively and in determining programs that ensure costeffectiveness.

The study of Clavenna et al. [224] highlights that there is a need to define (and to comply with) appropriate diagnostic and therapeutic approaches for child and adolescent psychiatric disorders such as major depressive disorder. The findings showed that the majority of children were not treated in psychiatric services aimed at children and adolescents. In most instances, psychotropic drugs were prescribed by general practitioners without the advice of child psychiatrists. This fact is a cause for concern, because little is known about the side effects of the use of psychotropic drugs in children in the long term. The early accurate identification and treatment of mood disorders can have direct and indirect impact on subsequent ages, reducing disability, costs and even mortality across the lifecycle [11].

Considering that childhood depression is a disease that can present many different ways, every treatment plan for depression in children and adolescents should take into consideration developmental aspects, including psychoeducation, family support, assessment of comorbid conditions, and risk behaviors. Moreover, given the nature of chronic and recurrent depressive disorders, clear objectives should be established together with patients and their families not only for the acute treatment of the current episode, but also for phases of consolidation and maintenance, monitoring and preventing new episodes [11].

Thus, a developmentally informed intervention should be sufficiently flexible to accommodate multiple sources of variability across young patients and explicate how its implementation for chronologically and/or developmentally younger patients differs from that for older youths [191]. (Figure 6)

Figure 6: Treatment's key features for child depression

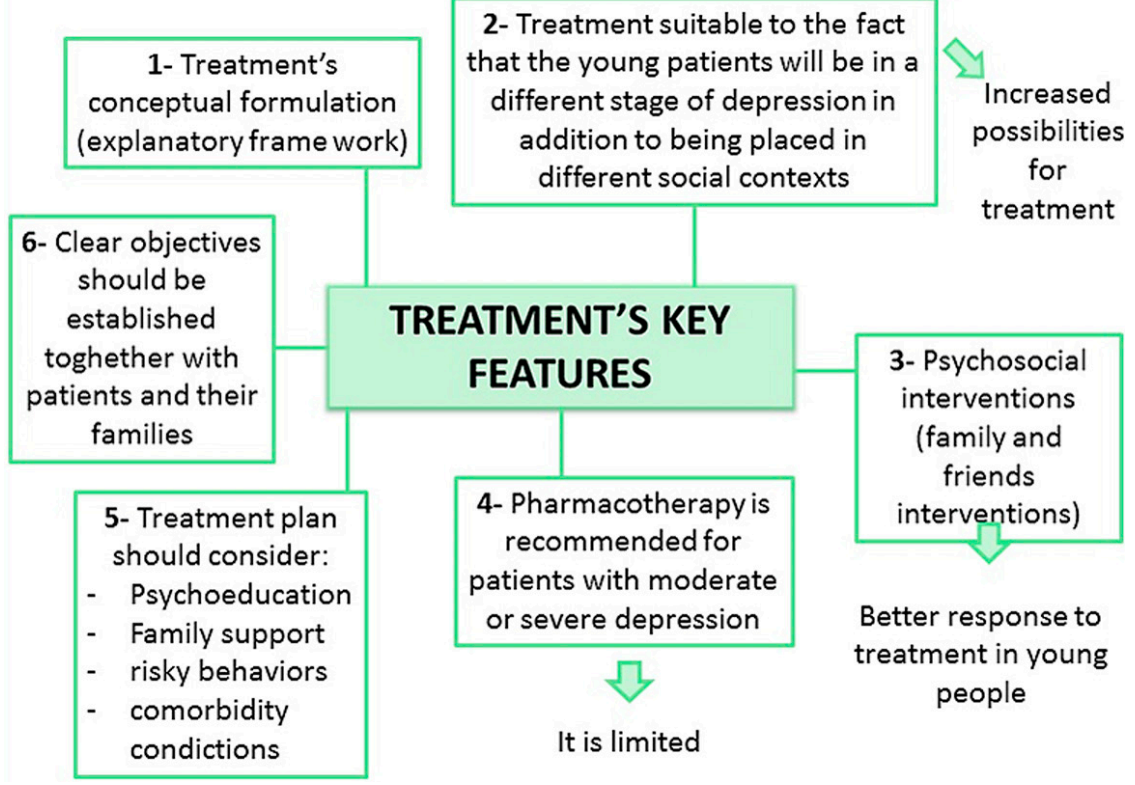




\section{Prognosis}

Early-onset depressive disorders can have serious consequences both in the aspects of development and functional. Recent studies suggest that depression in children may have negative impacts on their growth and development, school performance and family, relationships, and an important precursor to Psychopathology [162, 243, 244].

Besides the changes in social life, the emotional areas, and academics, as well as a wide range of psychiatric and health problems in adulthood [17, 245], depression in childhood can substantially increase the risk of drug abuse and suicide [4, 246]. Primary findings indicate that drug use initiation during early adolescence (e. g., ages 14-16) may not be tied to immediate proximal perturbations in risk factors, such as traumatic experiences and depressive symptoms. Rather, the effects of trauma on depression in this sample appear to be established earlier in childhood (ages 10-14 or younger) and persist in a relatively stable manner into middle adolescence when the risk for drug use may be heightened [247].

Anxiety and depression are not only associated with limitations in children's current functioning (e. g., poor social relations and academic performance, low self-esteem) [248, 249], these disorders can also negatively affect children's emotional and social long term development [249].

Some studies reported the relationship between depression and obesity in boys and girls [164, 165], whereas other studies reported the relationship in girls only [164, 166, 167].

Mental disorders emerge in childhood and adolescence and are important risk factors for mental disorders in adolescence and adulthood [183,250, 251]. Depression can have significant lasting effects when diagnosed in childhood and adolescence, and has been associated with later interpersonal difficulties, early parenthood, impaired school performance, unemployment, and other mental disorders and substance use disorders [185, 252-254].
Previous research demonstrating a longitudinal relationship between social withdrawal and negative social outcomes [99, 202] as well as a prospective link between interpersonal difficulties and depression [202, 255].

According to OgBuRn et al. [48] the families with major depressive disorder children showed higher levels of conflict and lower levels of cohesion, expressiveness and active-recreational orientation compared to the families without mentally ill children. In addition, families with major depressive disorder children show a lower degree of commitment, provide less support to one another, provide less encouragement to express feelings and have more conflicts compared to families with no mentally ill children or parents.

This situation may further complicate the situation of children with depression, for certain interpersonal characteristics such as high levels of "expressed emotion" (described as criticism, hostility or emotional over involvement of caregivers toward a family member suffering from a psychiatric illness) can negatively influence the treatment and prognosis of several psychiatric disorders, including unipolar depression and Bipolar Disorder [48, 256-258].

\section{Prevention}

Given the high prevalence of this disease and its widespread impact on youth, there is a critical need to identify the precursors of developing depressive disorders, as well as main indicators of time in development that create opportunities to prevent depression [162]. More specifically, the identification of contextual factors that contribute to the onset of childhood depression may help improve prevention and intervention efforts for this population [17].

Early prevention of these disorders is of utmost importance. This may not only have individual benefits with respect to children's current and future wellbeing, but may also serve society as a whole by reducing societal costs related to these problems (e. 
g., school drop-out, employment problems, health care use, medication) [248, 249].

Research has established a strong link between environment stress and internalizing problems in children [56, 259]. For children, their family is their closest environment. Not surprisingly, studies have shown that family stress is associated with anxiety and depression. In this context, important positive aspects of the family environment that contribute to the reduction and prevention of depressive disorder in children include supportive and facilitative interactions, and the absence of conflict [56].

Since schools offer the opportunity of reaching large groups of children, they are regarded as a suitable setting for the detection, prevention and early treatment of anxiety and depression [249, 260, 261]. In this sense, Gershon et. al. [70] suggest that schools may be a logical place to implement interventions aimed at reducing behavioral stress among children of depressed parents. The findings also suggest that there may be modifiable risk factors, such as the adolescent's coping skills, which can be targeted through early interventions to help identify and change the ways in which stress is self-generated. Having supportive friendships has traditionally been viewed as a protective factor that reduces risk for the development of depression during childhood and adolescence [262, 263].

Still in the context of the school environment, Kösters et al. [249] emphasize the importance of using the program "FRIENDS for Life". This program can be used for the prevention and treatment of anxiety and depression in children [249, 264-267]. This cognitive-behavioral program teaches children skills to cope more effectively with feelings of anxiety and depression and builds emotional resilience, problem-solving abilities and self-confidence. In their study, Kösters et al. [249] provide information on the effectiveness of the implementation of "FRIENDS for Life" as a program indicated prevention in schools for children with early or mild signs of anxiety or depression.
Already CHEN et al. [118] point out the importance of identifying the factors that contribute to reduced hippocampal volume in individuals at high risk of major depressive disorder, because this will be critical in helping to understand the inheritance mechanisms of risk of this disorder.

Identifying early markers of vulnerability in the context of familial risk is of particular importance in understanding the developmental course of depression and potential mechanisms for its intergenerational transmission [57], thus being an important factor in the search for prevention of depression in children.

What is evident in the literature is that a family environment characterized by inadequate parenting behaviors [111,112], repetitive maternal criticism of the children [17], divorced parents [268] or the manifestation of the psychopathology of depression in a parent [57-60] appear to be closely linked to the onset of depressive disorders in children. So, the presence of the family dynamics difficulties would be a risk factor for the development of depressive symptoms in children, as well as their maintenance. In this sense, peer and family contexts could have relevance for treatment responses, as youth with depression exhibit differences from healthy youth in their social behavior in both family contexts $[193,269]$ and peer contexts $[193,270]$. The family thus is revealed in a protective position, to prevent the children to develop depressive symptoms, and if they arise, are able to contribute to their recovery

Therefore, understanding the relationship of multiple factors associated with childhood depression may lead to the identification of those at risk and the establishment of preventive protocols and early intervention [126]. However, despite all knowledge we have about the importance of early prevention, only a minority of children with anxiety and depression receive mental health care for their problems [249, 271-273]. Therefore, preventive strategies for high-risk individuals, as well as cost-effectiveness 
analyses for better definition of public policies should be considered priorities in future research [11].

\section{Conclusion}

Current scientific literature dealing with childhood depression converges to, directly or indirectly; highlight the negative impact of depressive disorders for the child's quality of life.

The presented studies show that childhood depression is a disorder that develops most commonly in poverty and vulnerability scenery where the individual and family needs concerning to child depression are not always taken into account. In this context, this review demonstrates that depression that starts in childhood often leads to other psychiatric disorders and comorbidities, failing to serve as a warning for families to seek appropriate treatment while it is still possible to quickly reverse the negative consequences for children's mental health.

Even though there are no longer any doubts about its occurrence $[18,274]$, many gaps in knowledge still exist regarding childhood depression. There is no agreement about the criteria to be used to identify this condition in population-based studies. Prevalence varies depending on the age range studied. Factors associated with this disorder are also very different depending on the criterion used to identify depression, the setting and the age range of the studied population [18, 20, 275, 276].

According to the studies selected, it can be concluded that depression in childhood is not simply a mood regulation disorder; it also involves alterations in the physiology and in the cognitive and social functions of children, and requires comprehension of developmental integration processes at multiple levels of biological, psychological, and social complexity in individuals [8, 277].

In the analyzed studies, individual, family and environmental factors have been documented as psychosocial factors of childhood depression. Indi- vidual factors included age, gender, psychological and physical vulnerability $[8,22]$, comorbidity with other disorders [8, 23], emotional disturbance, impaired sociability, low self-esteem and social skills difficulties [8, 24, 25]. Family factors associated with childhood depression vulnerabilities consist of child abuse and marital conflict [8, 26, 27]; parental depression $[8,28]$; rejection and low interaction with the child [8, 29]; losses related to separation and death $[8,30]$ and a history of insecure attachment [8, 31, 32]. Lastly, environmental factors include daily difficulties, stressful or traumatic life events [8, $33,34]$, lack of social support and poor friendships $[8,12,27-34]$.

In clinical cases, it was observed that emphasizes its relationship to depression negative emotional experiences and traumatic events during childhood. It is noteworthy, however, that not all individuals exposed to childhood adversity develop depression, and genotype may moderate the relationship between childhood adversity and mental health outcomes [115, 124, 125]. This fact indicates that the etiology of depressive disorders is complex and multi-factorial, with an intricate interaction among environmental factors and genetic predisposition [126].

According to current literature, the human being involved in care, in particular the team of health professionals is not adequately trained to deal with child depression [222]. Thus, further research is necessary focused on the development of programs designed to prepare health professionals to deal directly or indirectly with childhood depression in the family and clinical environment, enabling them to detect and properly treat this disease, minimizing its destructive effects.

\section{Acknowledgements}

We are grateful to the Suicidology Research group - Federal University of Ceará (UFC)/National Council for Scientific and Technological Development (CNPq). We would also like to the Scientific Writing 
Lab (LABESCI) -Federal University of Cariri (UFCA), which always supported the work on this manuscript.

\section{Role of Funding Source}

We have no foundation source.

\section{Conflict of Interest}

The authors have no conflicts of interest or financial ties to report.

\section{Contributors}

Dr Rolim Lima, Mr Pimentel, Mr Grangeiro, Ms Pinheiro: mapping and categorization of information.

Dr. Sampaio, Mr. Teixeira: data analysis.

Mr. Aguiar, Mr. Pereira: review of the information and formatting the article.

Ms Meireles, Ms. Maia, Ms. Miná: elaboration of conceptual maps.

Drs. Rolim-Neto, Nascimento: responsible for study design.

All authors contributed to and have approved the final manuscript.

\section{References}

1. Weir, J. M., Zakama, A. \& Rao, U. Developmental risk I: depression and the developing brain. Child Adolesc. Psychiatr. Clin. N. Am. 21, 237-259 (2012).

2. Clark, M. S., Jansen, K. L. \& Anthony Cloy, J. Treatment of childhood and adolescent depression. Am. Fam. Physician 86, 442 (2012).

3. Lewinsohn, P. M., Rohde, P., Klein, D. N. \& Seeley, J. R. Natural course of adolescent major depressive disorder: I. Continuity into young adulthood. J. Am. Acad. Child Adolesc. Psychiatry 38, 56-63 (1999).

4. Mihalopoulos, C., Vos, T., Pirkis, J. \& Carter, R. The Population Cost-effectiveness of Interventions Designed to Prevent Childhood Depression. Pediatrics 129, e723-e730 (2012).

5. Jane Costello, E., Erkanli, A. \& Angold, A. Is there an epidemic of child or adolescent depression? J. Child Psychol. Psychiatry 47, 1263-1271 (2006).

6. Steinhausen, H. -C. \& Winkler Metzke, C. Prevalence of affective disorders in children and adolescents: findings from the Zurich Epidemiological Studies. Acta Psychiatr. Scand. 108, 20-23 (2003).
7. Ford, T., Goodman, R. \& Meltzer, H. The British child and adolescent mental health survey 1999: the prevalence of DSMIV disorders. J. Am. Acad. Child Adolesc. Psychiatry 42, 12031211 (2003).

8. Avanci, J. Q., Assis, S. G., Oliveira, R., Pires, T. \& others. Childhood depression. Exploring the association between family violence and other psychosocial factors in low-income Brazilian schoolchildren. Child Adolesc. Psychiatry Ment. Health 6, 1-9 (2012).

9. Fleitlich-Bilyk, B. \& Goodman, R. Prevalence of child and adolescent psychiatric disorders in southeast Brazil. J. Am. Acad. Child Adolesc. Psychiatry 43, 727-734 (2004).

10. De Mattos Souza, L. D. et al. Sintomatologia depressiva em adolescentes iniciais-estudo de base populacional. J Bras Psiquiatr 57, 261-266 (2008)

11. Rocha, T. B. M., Zeni, C. P., Caetano, S. C. \& Kieling, C. Mood disorders in childhood and adolescence. Rev. Bras. Psiquiatr. 35, S22-S31 (2013).

12. Birmaher, B. et al. Childhood and adolescent depression: a review of the past 10 years. Part I. J. Am. Acad. Child Adolesc. Psychiatry 35, 1427-1439 (1996).

13. Rutherford, B. R. et al. Deconstructing pediatric depression trials: an analysis of the effects of expectancy and therapeutic contact. J. Am. Acad. Child Adolesc. Psychiatry 50, 782-795 (2011).

14. Aravind, V. K. \& Krishnaram, V. D. Childhood depression with unremitting suicidal behavior. Indian J. Psychol. Med. 32, 146 (2011).

15. Middeldorp, C. M. et al. Anxiety and depression in children and adults: influence of serotonergic and neurotrophic genes? Genes Brain Behav. 9, 808-816 (2010).

16. Avenevoli, S., Knight, E., Kessler, R. C. \& Merikangas, K. R. in Handbook of depression in children and adolescents 6-32 (2008).

17. Burkhouse, K. L., Uhrlass, D. J., Stone, L. B., Knopik, V. S. \& Gibb, B. E. Expressed Emotion-Criticism and Risk of Depression Onset in Children. J. Clin. Child Adolesc. Psychol. 41, 771-777 (2012).

18. Pereira, T. S. et al. Perinatal and early life factors associated with symptoms of depression in Brazilian children. BMC Public Health 12, 605 (2012).

19. Banh, M. K. et al. Measurement Equivalence Across Racial/Ethnic Groups of the Mood and Feelings Questionnaire for Childhood Depression. J. Abnorm. Child Psychol. 40, 353-367 (2012).

20. Saluja, G. et al. Prevalence of and risk factors for depressive symptoms among young adolescents. Arch. Pediatr. Adolesc. Med. 158, 760-765 (2004).

21. American Psychiatric Association. Diagnostic and statistical manual of mental disorders. (2000).

22. Rao, U. et al. Hippocampal Changes Associated with Early-Life Adversity and Vulnerability to Depression. Biol. Psychiatry 67, 357-364 (2010). 
23. Lewinsohn, P. M., Clarke, G. N., Seeley, J. R. \& Rohde, P. Major depression in community adolescents: age at onset, episode duration, and time to recurrence. J. Am. Acad. Child Adolesc. Psychiatry 33, 809-818 (1994).

24. Segrin, C. Social skills deficits associated with depression. Clin. Psychol. Rev. 20, 379-403 (2000).

25. Orth, U., Robins, R. W. \& Meier, L. L. Disentangling the effects of low self-esteem and stressful events on depression: findings from three longitudinal studies. J. Pers. Soc. Psychol. 97, 307 (2009).

26. Reynolds, M. W., Wallace, J., Hill, T. F., Weist, M. D. \& Nabors, L. A. The relationship between gender, depression, and selfesteem in children who have witnessed domestic violence. Child Abuse Negl. 25, 1201-1206 (2001)

27. Kennedy, A. C., Bybee, D., Sullivan, C. M. \& Greeson, M. The impact of family and community violence on children's depression trajectories: Examining the interactions of violence exposure, family social support, and gender. J. Fam. Psychol. 24, 197 (2010).

28. Bagner, D. M., Pettit, J. W., Lewinsohn, P. M. \& Seeley, J. R. Effect of maternal depression on child behavior: a sensitive period? J. Am. Acad. Child Adolesc. Psychiatry 49, 699-707 (2010).

29. Hale, W. W., Van Der Valk, I., Engels, R. \& Meeus, W. Does perceived parental rejection make adolescents sad and mad? The association of perceived parental rejection with adolescent depression and aggression. J. Adolesc. Health 36, 466-474 (2005).

30. Gray, L. B., Weller, R. A., Fristad, M. \& Weller, E. B. Depression in children and adolescents two months after the death of a parent. J. Affect. Disord. 135, 277-283 (2011).

31. Hennessy, M. B., Deak, T. \& Schiml-Webb, P. A. Early attachmentfigure separation and increased risk for later depression: potential mediation by proinflammatory processes. Neurosci. Biobehav. Rev. 34, 782-790 (2010)

32. Burnette, J. L., Davis, D. E., Green, J. D., Worthington, E. L. \& Bradfield, E. Insecure attachment and depressive symptoms: The mediating role of rumination, empathy, and forgiveness. Personal. Individ. Differ. 46, 276-280 (2009).

33. Goodyer, I. M. Life events: Their nature and effects. Depress. Child Adolesc. 2, 204-32 (2001).

34. Mayer, L. et al. Stressful life events in a clinical sample of depressed children in Hungary. J. Affect. Disord. 115, 207-214 (2009).

35. Bandiera, F. C., Richardson, A. K., Lee, D. J., He, J. -P. \& Merikangas, K. R. Secondhand smoke exposure and mental health among children and adolescents. Arch. Pediatr. Adolesc. Med. 165, 332-338 (2011).

36. Glantz, S. A. \& Parmley, W. W. Passive smoking and heart disease: mechanisms and risk. Jama 273, 1047-1053 (1995).

37. Lai, H. -K., Ho, S. -Y., Wang, M. -P. \& Lam, T. -H. Secondhand smoke and respiratory symptoms among adolescent current smokers. Pediatrics 124, 1306-1310 (2009).
38. Wang, C. et al. Effects of in utero and childhood tobacco smoke exposure and $\beta 2$-adrenergic receptor genotype on childhood asthma and wheezing. Pediatrics 122, e107-e114 (2008).

39. Monroe, S. M., Harkness, K., Simons, A. D. \& Thase, M. E. Life stress and the symptoms of major depression. J. Nerv. Ment. Dis. 189, 168-175 (2001)

40. Monroe, S. M. \& Simons, A. D. Diathesis-stress theories in the context of life stress research: implications for the depressive disorders. Psychol. Bull. 110, 406 (1991).

41. Flier, J. S., Underhill, L. H. \& McEwen, B. S. Protective and damaging effects of stress mediators. N. Engl. J. Med. 338, 171179 (1998)

42. Evans, G. W. A multimethodological analysis of cumulative risk and allostatic load among rural children. Dev. Psychol. 39, 924 (2003).

43. Evans, G. W., Kim, P., Ting, A. H., Tesher, H. B. \& Shannis, D. Cumulative risk, maternal responsiveness, and allostatic load among young adolescents. Dev. Psychol. 43, 341 (2007).

44. Johnston-Brooks, C. H., Lewis, M. A., Evans, G. W. \& Whalen, C. K. Chronic stress and illness in children: the role of allostatic load. Psychosom. Med. 60, 597-603 (1998).

45. Brody, A. L. et al. Gene variants of brain dopamine pathways and smoking-induced dopamine release in the ventral caudate/ nucleus accumbens. Arch. Gen. Psychiatry 63, 808-816 (2006).

46. Caskey, N. H. et al. Modulating tobacco smoking rates by dopaminergic stimulation and blockade. Nicotine Tob. Res. 4, 259-266 (2002).

47. Caskey, N. H., Jarvik, M. E. \& Wirshing, W. C. The effects of dopaminergic D2 stimulation and blockade on smoking behavior. Exp. Clin. Psychopharmacol. 7, 72-78 (1999).

48. Ogburn, K. M. et al. Family Environment and Pediatric Major Depressive Disorder. Psychopathology 43, 312-318 (2010).

49. Althoff, R. R., Faraone, S. V., Rettew, D. C., Morley, C. P. \& Hudziak, J. J. Family, twin, adoption, and molecular genetic studies of juvenile Bipolar Disorder. Bipolar Disord. 7, 598-609 (2005).

50. Yap, M. B., Allen, N. B. \& Sheeber, L. Using an emotion regulation framework to understand the role of temperament and family processes in risk for adolescent depressive disorders. Clin. Child Fam. Psychol. Rev. 10, 180-196 (2007).

51. Essex, M. J. etal. Influence of early life stress on later hypothalamicpituitary-adrenal axis functioning and its covariation with mental health symptoms: A study of the allostatic process from childhood into adolescence. Dev. Psychopathol. 23, 1039-1058 (2011).

52. Essex, M. J. et al. Exploring risk factors for the emergence of children's mental health problems. Arch. Gen. Psychiatry 63, 1246-1256 (2006).

53. Halligan, S. L., Herbert, J., Goodyer, I. \& Murray, L. Disturbances in morning cortisol secretion in association with maternal postnatal depression predict subsequent depressive symptomatology in adolescents. Biol. Psychiatry 62, 40-46 (2007). 
54. Kim, J., Cicchetti, D., Rogosch, F. A. \& Manly, J. T. Child maltreatment and trajectories of personality and behavioral functioning: Implications for the development of personality disorder. Dev. Psychopathol. 21, 889-912 (2009).

55. Trickett, P. K., Negriff, S., Ji, J. \& Peckins, M. Child maltreatment and adolescent development. J. Res. Adolesc. 21, 3-20 (2011).

56. Van Oort, F. V. A., Verhulst, F. C., Ormel, J. \& Huizink, A. C. Prospective community study of family stress and anxiety in (pre) adolescents: the TRAILS study. Eur. Child Adolesc. Psychiatry 19, 483-491 (2010).

57. Feng, X. et al. Children's Depressive Symptoms in Relation to EEG Frontal Asymmetry and Maternal Depression. J. Abnorm. Child Psychol. 40, 265-276 (2012).

58. Potter, R. et al. Missed opportunities: mental disorder in children of parents with depression. Br. J. Gen. Pract. 62, e487-e493 (2012).

59. Suglia, S. F., Ryan, L., Bellinger, D. C., Enlow, M. B. \& Wright, R. J. Children's exposure to violence and distress symptoms: influence of caretakers' psychological functioning. Int. J. Behav. Med. 18, 35-43 (2011).

60. Weitzman, M., Rosenthal, D. G. \& Liu, Y. -H. Paternal Depressive Symptoms and Child Behavioral or Emotional Problems in the United States. Pediatrics 128, 1126-1134 (2011).

61. Joormann, J., Gilbert, K. \& Gotlib, I. H. Emotion identification in girls at high risk for depression. J. Child Psychol. Psychiatry 51, 575-582 (2010)

62. Lewis, G., Rice, F., Harold, G. T., Collishaw, S. \& Thapar, A. Investigating Environmental Links Between Parent Depression and Child Depressive/Anxiety Symptoms Using an Assisted Conception Design. J. Am. Acad. Child Adolesc. Psychiatry 50, 451-459. e1 (2011).

63. Weissman, M. M. et al. Offspring of depressed parents: 20 years later. (2006). at <http://ajp. psychiatryonline. org/doi/abs/10. 1176/ajp. 2006. 163. 6. 1001>

64. Merikangas, K. R., Prusoff, B. A. \& Weissman, M. M. Parental concordance for affective disorders: Psychopathology in offspring. J. Affect. Disord. 15, 279-290 (1988).

65. Beardslee, W. R. et al. Prediction of adolescent affective disorder: Effects of prior parental affective disorders and child Psychopathology. J. Am. Acad. Child Adolesc. Psychiatry 35, 279-288 (1996)

66. Harrington, R. Family-genetic findings in child and adolescent depressive disorders. Int. Rev. Psychiatry 8, 355-368 (1996).

67. Kim-Cohen, J., Caspi, A., Rutter, M., Tomás, M. P. \& Moffitt, T. E. The caregiving environments provided to children by depressed mothers with or without an antisocial history. Am. J. Psychiatry 163, 1009-1018 (2006)

68. Pilowsky, D. J. et al. Children of depressed mothers 1 year after the initiation of maternal treatment: findings from the STAR* D-Child Study. (2008). at <http://ajp. psychiatryonline. org/doi/ abs/10. 1176/appi. ajp. 2008. 07081286>
69. Silberg, J. L., Maes, H. \& Eaves, L. J. Genetic and environmental influences on the transmission of parental depression to children's depression and conduct disturbance: an extended Children of Twins study: Genetic and environmental influences on the transmission of parental depression. J. Child Psychol. Psychiatry 51, 734-744 (2010).

70. Gershon, A. et al. Life stress and first onset of psychiatric disorders in daughters of depressed mothers. J. Psychiatr. Res. 45, 855-862 (2011).

71. Hammen, C. in Handbook of Depression 275-297 (Guilford Press, 2009)

72. Joormann, J., Eugene, F. \& Gotlib, I. H. in Handbook of depression in adolescents (Erlbaum, 2008).

73. Weissman, M. M., Warner, V., Wickramaratne, P., Moreau, D. \& Olfson, M. Offspring of depressed parents: 10 years later. Arch. Gen. Psychiatry 54, 932-940 (1997).

74. Davies, P. T. \& Windle, M. Gender-specific pathways between maternal depressive symptoms, family discord, and adolescent adjustment. Dev. Psychol. 33, 657 (1997).

75. Hops, H. in Interpersonal factors in the origin and course of affective disorders 113-129 (Royal College of Psychiatrists, 1996).

76. McAdams, T. A., Gregory, A. M. \& Eley, T. C. Genes of Experience: Explaining the Heritability of Putative Environmental Variables Through Their Association with Behavioural and Emotional Traits. Behav. Genet. 43, 314-328 (2013).

77. Plomin, R., Defries, J., McClearn, G. \& McGuffin, P. Behavioral genetics. (Worth Publishers, 2008).

78. Thapar, A. \& McGuffin, P. A twin study of depressive symptoms in childhood. Br. J. Psychiatry 165, 259-265 (1994).

79. Tackett, J. L., Waldman, I. D., Van Hulle, C. A. \& Lahey, B. B. Shared Genetic Influences on Negative Emotionality and Major Depression/Conduct Disorder Comorbidity. J. Am. Acad. Child Adolesc. Psychiatry 50, 818-827 (2011).

80. Bureau, J. -F., Easterbrooks, M. \& Lyons-Ruth, K. Maternal depressive symptoms in infancy: Unique contribution to children's depressive symptoms in childhood and adolescence? Dev. Psychopathol. 21, 519-537 (2009).

81. Liu, R. T., Jager-Hyman, S., Wagner, C. A., Alloy, L. B. \& Gibb, B. E. Number of childhood abuse perpetrators and the occurrence of depressive episodes in adulthood. Child Abuse Negl. 36, 323332 (2012)

82. Bedi, S. et al. Risk for suicidal thoughts and behavior after childhood sexual abuse in women and men. Suicide Life. Threat. Behav. 41, 406-415 (2011).

83. Bennett, D. S., Sullivan, M. W. \& Lewis, M. Neglected Children, Shame-Proneness, and Depressive Symptoms. Child Maltreat. 15, 305-314 (2010)

84. Osofsky, J. D. Prevalence of children's exposure to domestic violence and child maltreatment: Implications for prevention and intervention. Clin. Child Fam. Psychol. Rev. 6, 161-170 (2003). 
85. Sedlak, A. J. et al. Fourth national incidence study of child abuse and neglect (NIS-4). Wash. DC US Dep. Health Hum. Serv. Retrieved July 9, 2010 (2010).

86. Buka, S. L., Stichick, T. L., Birdthistle, I. \& Earls, F. J. Youth exposure to violence: prevalence, risks, and consequences. Am. J. Orthopsychiatry 71, 298 (2001).

87. Tracy, M., Zimmerman, F. J., Galea, S., McCauley, E. \& Vander Stoep, A. What explains the relation between family poverty and childhood depressive symptoms? J. Psychiatr. Res. 42, 11631175 (2008)

88. Lewis, M. in Handbook of emotions 623-636 (Guilford, 2000).

89. Alessandri, S. M. \& Lewis, M. Differences in pride and shame in maltreated and nonmaltreated preschoolers. Child Dev. 67, 1857-1869 (1996).

90. Bennett, D. S., Sullivan, M. W. \& Lewis, M. Young children's adjustment as a function of maltreatment, shame, and anger. Child Maltreat. 10, 311-323 (2005).

91. Feiring, C., Taska, L. \& Lewis, M. The role of shame and attributional style in children's and adolescents' adaptation to sexual abuse. Child Maltreat. 3, 129-142 (1998).

92. Kelley, S. A., Brownell, C. A. \& Campbell, S. B. Mastery Motivation and Self-Evaluative Affect in Toddlers: Longitudinal Relations with Maternal Behavior. Child Dev. 71, 1061-1071 (2000).

93. Mills, R. S. Possible antecedents and developmental implications of shame in young girls. Infant Child Dev. 12, 329-349 (2003).

94. Stuewig, J. \& McCloskey, L. A. The relation of child maltreatment to shame and guilt among adolescents: Psychological routes to depression and delinquency. Child Maltreat. 10, 324-336 (2005).

95. Luby, J. et al. Shame and guilt in preschool depression: evidence for elevations in self-conscious emotions in depression as early as age 3. J. Child Psychol. Psychiatry 50, 1156-1166 (2009).

96. Tilghman-Osborne, C., Cole, D. A., Felton, J. W. \& Ciesla, J. A. Relation of guilt, shame, behavioral and characterological selfblame to depressive symptoms in adolescents over time. J. Soc. Clin. Psychol. 27, 809 (2008).

97. Lewis, H. B. in The role of shame in symptom formation 29 50 (Lawrence Erlbaum, 1987). at <http://psycnet. apa. org/ psycinfo/1987-97906-002>

98. Lewis, M. Shame: The exposed self. (The Free Press, 1992).

99. Rubin, K. H., Coplan, R. J. \& Bowker, J. C. Social withdrawal in childhood. Annu. Rev. Psychol. 60, 141 (2009).

100. Tangney, J. P. in Symptoms of depression 101, 161-180 (Costello, CG., 1993).

101. Tangney, J. P., Wagner, P. \& Gramzow, R. Proneness to shame, proneness to guilt, and psychopathology. J. Abnorm. Psychol. 101, 469 (1992).

102. Joiner, T. E. \& Wagner, K. D. Attributional style and depression in children and adolescents: A meta-analytic review. Clin. Psychol. Rev. 15, 777-798 (1995).
103. Lewis, $M$. in The self-conscious emotions: Theory and research 134-149 (Guilford, 2007).

104. Antonijevic, I. A. Depressive disorders-is it time to endorse different pathophysiologies? Psychoneuroendocrinology 31, 1-15 (2006).

105. Dickerson, S. S., Gruenewald, T. L. \& Kemeny, M. E. When the social self is threatened: Shame, physiology, and health. J. Pers. 72, 1191-1216 (2004).

106. Schoenfelder, E. N., Sandler, I. N., Wolchik, S. \& MacKinnon, D. Quality of Social Relationships and the Development of Depression in Parentally-Bereaved Youth. J. Youth Adolesc. 40, 85-96 (2011).

107. Kendler, K. S., Sheth, K., Gardner, C. O. \& Prescott, C. A. Childhood parental loss and risk for first-onset of major depression and alcohol dependence: the time-decay of risk and sex differences. Psychol. Med. 32, 1187-1194 (2002).

108. Reinherz, H. Z., Giaconia, R. M., Hauf, A. M. C., Wasserman, M. S. \& Silverman, A. B. Major depression in the transition to adulthood: risks and impairments. J. Abnorm. Psychol. 108, 500 (1999).

109. Hipwell, A. E. et al. Impact of oppositional defiant disorder dimensions on the temporal ordering of conduct problems and depression across childhood and adolescence in girls: ODD dimensions, conduct problems and depression in girls. J. Child Psychol. Psychiatry 52, 1099-1108 (2011).

110. Keenan, K. \& Shaw, D. Developmental and social influences on young girls' early problem behavior. Psychol. Bull. 121, 95 (1997).

111. Greenfield, E. A. \& Marks, N. F. Identifying experiences of physical and psychological violence in childhood that jeopardize mental health in adulthood. Child Abuse Negl. 34, 161-171 (2010).

130. Parker, K. J., Schatzberg, A. F. \& Lyons, D. M. Neuroendocrine aspects of hypercortisolism in major depression. Horm. Behav. 43, 60-66 (2003).

131. Burke, H. M., Davis, M. C., Otte, C. \& Mohr, D. C. Depression and cortisol responses to psychological stress: A meta-analysis. Psychoneuroendocrinology 30, 846-856 (2005).

132. El-Sheikh, M. \& Arsiwalla, D. D. Children's sleep, skin conductance level and mental health: Sleep and children's SCL. J. Sleep Res. 20, 326-337 (2011).

133. Khantzian, E. J. The self-medication hypothesis of substance use disorders: a reconsideration and recent applications. Harv. Rev. Psychiatry 4, 231-244 (1997).

134. Olvera, R. L. et al. Reduced medial prefrontal N-AcetylAspartate levels in pediatric major depressive disorder: A multi-voxel in vivo1H spectroscopy study. Psychiatry Res. Neuroimaging 184, 71-76 (2010).

135. Drevets, W. C. et al. Subgenual prefrontal cortex abnormalities in mood disorders. (1997). at <http://www.nature.com/ articles/386824a0> 
136. Rajkowska, G. et al. Morphometric evidence for neuronal and glial prefrontal cell pathology in major depression. Biol. Psychiatry 45, 1085-1098 (1999).

137. Botteron, K. N., Raichle, M. E., Drevets, W. C., Heath, A. C. \& Todd, R. D. Volumetric reduction in left subgenual prefrontal cortex in early onset depression. Biol. Psychiatry 51, 342-344 (2002).

138. Bremner, J. D. et al. Reduced volume of orbitofrontal cortex in major depression. Biol. Psychiatry 51, 273-279 (2002).

139. Sheline, Y. I. Neuroimaging studies of mood disorder effects on the brain. Biol. Psychiatry 54, 338-352 (2003).

140. Steingard, R. J. et al. Structural abnormalities in brain magnetic resonance images of depressed children. J. Am. Acad. Child Adolesc. Psychiatry 35, 307-311 (1996).

141. Nolan, C. L. et al. Prefrontal cortical volume in childhood-onset major depression: preliminary findings. Arch. Gen. Psychiatry 59, 173-179 (2002).

142. Campbell, S., Marriott, M., Nahmias, C. \& MacQueen, G. M. Lower hippocampal volume in patients suffering from depression: a meta-analysis. (2004). at <http://ajp. psychiatryonline.org/doi/10.1176/appi.ajp.161.4.598>

143. Frodl, T., Möller, H.-J. \& Meisenzahl, E. Neuroimaging genetics: new perspectives in research on major depression? Acta Psychiatr. Scand. 118, 363-372 (2008).

144. Videbech, P., Ravnkilde, B. \& others. Hippocampal volume and depression: a meta-analysis of MRI studies. Am. J. Psychiatry 161, 1957-1966 (2004).

145. MacMaster, F. P. et al. Amygdala and hippocampal volumes in familial early onset major depressive disorder. Biol. Psychiatry 63, 385-390 (2008).

146. Gould, N. F. etal. Performance on a virtual reality spatial memory navigation task in depressed patients. (2007). at <http://ajp. psychiatryonline.org/doi/abs/10.1176/ajp.2007.164.3.516>

147. Nestler, E. J. et al. Neurobiology of depression. Neuron 34 13-25 (2002).

148. Gotlib, I. H. et al. Neural processing of reward and loss in girls at risk for major depression. Arch. Gen. Psychiatry 67, 380387 (2010).

149. Mazefsky, C. A., Conner, C. M. \& Oswald, D. P. Association between depression and anxiety in high-functioning children with autism spectrum disorders and maternal mood symptoms. Autism Res. 3, 120-127 (2010).

150. Ghaziuddin, M., Ghaziuddin, N. \& Greden, J. Depression in persons with autism: Implications for research and clinical care. J. Autism Dev. Disord. 32, 299-306 (2002).

151. White, S. W., Oswald, D., Ollendick, T. \& Scahill, L. Anxiety in children and adolescents with autism spectrum disorders. Clin. Psychol. Rev. 29, 216-229 (2009)

152. Lainhart, J. E. Psychiatric problems in individuals with autism, their parents and siblings. Int. Rev. Psychiatry 11, 278-298 (1999).
153. Hyphantis, T. N. et al. Depressive Symptoms and Neurocardiogenic Syncope in Children: A 2-Year Prospective Study. PEDIATRICS 130, 906-913 (2012).

154. Ventura, R. et al. Psychiatric conditions in patients with recurrent unexplained syncope. Europace 3, 311-316 (2001).

155. Kouakam, C. et al. Prevalence and prognostic significance of psychiatric disorders in patients evaluated for recurrent unexplained syncope. Am. J. Cardiol. 89, 530-535 (2001).

156. Leftheriotis, D. et al. Minor psychiatric disorders and syncope: the role of psychopathology in the expression of vasovagal reflex. Psychother. Psychosom. 77, 372-376 (2008).

157. D'Antono, B. et al. Prospective evaluation of psychological distress and psychiatric morbidity in recurrent vasovagal and unexplained syncope. J. Psychosom. Res. 67, 213-222 (2009).

158. McGrady, A., KERN-BUELL, C., Bush, E., Khuder, S. \& Grubb, B. P. Psychological and physiological factors associated with tilt table testing for neurally mediated syncopal syndromes. Pacing Clin. Electrophysiol. 24, 296-301 (2001).

159. Cohen, T. J. et al. An Association Between Anxiety and Neurocardiogenic Syncope During Head-Up Tilt Table Testing. Pacing Clin. Electrophysiol. 23, 837-841 (2000).

160. Giada, F. et al. Psychiatric profile, quality of life and risk of syncopal recurrence in patients with tilt-induced vasovagal syncope. Europace 7, 465-471 (2005).

161. Wakimizu, R. et al. Depression and health-related quality of life after discharge and associated factors in childhood cancer patients in Japan. Biosci. Trends 5, 264-272 (2011).

162. Lin, F.-G., Hsieh, Y., Tung, H.-J. \& others. Interactive effects of family socioeconomic status and body mass index on depression in school-aged children. Asia Pac. J. Clin. Nutr. 21, 64 (2012).

163. Melchior, M., Moffitt, T. E., Milne, B. J., Poulton, R. \& Caspi, A. Why do children from socioeconomically disadvantaged families suffer from poor health when they reach adulthood? A life-course study. Am. J. Epidemiol. 166, 966-974 (2007).

164. Duarte, C. S. et al. Child Mental Health Problems and Obesity in Early Adulthood. J. Pediatr. 156, 93-97 (2010).

165. Goodman, E. \& Whitaker, R. C. A prospective study of the role of depression in the development and persistence of adolescent obesity. Pediatrics 110, 497-504 (2002)

166. Anderson, S. E., Cohen, P., Naumova, E. N. \& Must, A. Relationship of childhood behavior disorders to weight gain from childhood into adulthood. Ambul. Pediatr. 6, 297-301 (2006).

167. Richardson, L. P. et al. A longitudinal evaluation of adolescent depression and adult obesity. Arch. Pediatr. Adolesc. Med. 157, 739-745 (2003).

168. Mustillo, S. et al. Obesity and psychiatric disorder: developmental trajectories. Pediatrics 111, 851-859 (2003).

169. Wojnar, J. et al. Sleep and body mass index in depressed children and healthy controls. Sleep Med. 11, 295-301 (2010). 
170. Ford, D. E. \& Kamerow, D. B. Epidemiologic study of sleep disturbances and psychiatric disorders: an opportunity for prevention? Jama 262, 1479-1484 (1989).

171. Perlis, M. L. et al. Insomnia as a risk factor for onset of depression in the elderly. Behav. Sleep. Med. 4, 104-113 (2006).

172. Weissman, M. M., Greenwald, S., Niño-Murcia, G. \& Dement, W. C. The morbidity of insomnia uncomplicated by psychiatric disorders. Gen. Hosp. Psychiatry 19, 245-250 (1997).

173. Keenan, K. et al. Lack of Assertion, Peer Victimization, and Risk for Depression in Girls: Testing a Diathesis-Stress Model. J. Adolesc. Health 47, 526-528 (2010).

174. Panak, W. F. \& Garber, J. Role of aggression, rejection, and attributions in the prediction of depression in children. Dev. Psychopathol. 4, 145-165 (1992).

175. Klomek, A. B., Marrocco, F., Kleinman, M., Schonfeld, I. S. \& Gould, M. S. Bullying, depression, and suicidality in adolescents. J. Am. Acad. Child Adolesc. Psychiatry 46, 40-49 (2007).

176. Wang, J., Nansel, T. R. \& lannotti, R. J. Cyber and Traditional Bullying: Differential Association With Depression. J. Adolesc. Health 48, 415-417 (2011).

177. Pellegrini, A. D. Bullies and victims in school: A review and call for research. J. Appl. Dev. Psychol. 19, 165-176 (1998).

178. Hawker, D. S. \& Boulton, M. J. Twenty years' research on peer victimization and psychosocial maladjustment: a metaanalytic review of cross-sectional studies. J. Child Psychol. Psychiatry 41, 441-455 (2000).

179. Smith, P. K. et al. Cyberbullying: Its nature and impact in secondary school pupils. J. Child Psychol. Psychiatry 49, 376385 (2008)

180. Uher, R. et al. Serotonin transporter gene moderates childhood maltreatment's effects on persistent but not singleepisode depression: Replications and implications for resolving inconsistent results. J. Affect. Disord. 135, 56-65 (2011).

181. Uddin, M. et al. Gender differences in the genetic and environmental determinants of adolescent depression. Depress. Anxiety 27, 658-666 (2010).

182. Gatt, J. M. et al. Interactions between BDNF Val66Met polymorphism and early life stress predict brain and arousal pathways to syndromal depression and anxiety. Mol. Psychiatry 14, 681-695 (2009).

183. In-Albon, T., Zumsteg, U., Müller, D. \& Schneider, S. Mental disorders in the pediatric setting-results of a Swiss survey. Swiss Med Wkly 140, w13092 (2010).

184. Bufferd, S. J., Dougherty, L. R., Carlson, G. A., Rose, S. \& Klein, D. N. Psychiatric disorders in preschoolers: continuity from ages 3 to 6. Am. J. Psychiatry 169, 1157-1164 (2012).

185. Cheung, A. H., Kozloff, N. \& Sacks, D. Pediatric depression: an evidence-based update on treatment interventions. Curr. Psychiatry Rep. 15, 1-8 (2013).
186. March, J. S. \& Albano, A. M. Assessment of anxiety in children and adolescents. Am. Psychiatr. Press Rev. Psychiatry (1996). at <http://psycnet.apa.org/psycinfo/2000-08919-017>

187. Southam-Gerow, M. \& Chorpita, B. F. in Assessment of child disorders 347-397 (Guilford, 2007)

188. Ebesutani, C. et al. A Psychometric Analysis of the Revised Child Anxiety and Depression Scales-Parent Version in a School Sample. J. Abnorm. Child Psychol. 39, 173-185 (2011).

189. Pagliaccio, D. et al. Anomalous functional brain activation following negative mood induction in children with preschool onset major depression. Dev. Cogn. Neurosci. 2, 256267 (2012).

190. Cole, D. A. et al. Structure and measurement of depression in youths: Applying item response theory to clinical data. Psychol. Assess. 23, 819-833 (2011).

191. Kovacs, M. \& Lopez-Duran, N. L. Contextual Emotion Regulation Therapy: A Developmentally Based Intervention for Pediatric Depression. Child Adolesc. Psychiatr. Clin. N. Am. 21, 327-343 (2012).

192. Association, A. P. \& others. Diagnostic and statistical manual of mental disorders, (DSM-5®). (American Psychiatric Pub, 2013)

193. Forbes, E. E. et al. Real-World Affect and Social Context as Predictors of Treatment Response in Child and Adolescent Depression and Anxiety: An Ecological Momentary Assessment Study. J. Child Adolesc. Psychopharmacol. 22, 37-47 (2012).

194. Maurer, D. M. Screening for depression. Am Fam Physician 139-144 (2012).

195. Birmaher, B., Brent, D., Issues, A. W. G. on Q. \& others. Practice parameter for the assessment and treatment of children and adolescents with depressive disorders. J. Am. Acad. Child Adolesc. Psychiatry 46, 1503-1526 (2007).

196. Calhoun, S. L. et al. Prevalence and risk factors of excessive daytime sleepiness in a community sample of young children: the role of obesity, asthma, anxiety/depression, and sleep. 34, 503-507 (2011).

197. Williams, S. B., O'Connor, E. A., Eder, M. \& Whitlock, E. P. Screening for child and adolescent depression in primary care settings: a systematic evidence review for the US Preventive Services Task Force. Pediatrics 123, e716-e735 (2009).

198. Barch, D. M., Gaffrey, M. S., Botteron, K. N., Belden, A. C. \& Luby, J. L. Functional Brain Activation to Emotionally Valenced Faces in School-Aged Children with a History of PreschoolOnset Major Depression. Biol. Psychiatry 72, 1035-1042 (2012).

199. Richardson, L. P. \& Katzenellenbogen, R. Childhood and adolescent depression: the role of primary care providers in diagnosis and treatment. Curr. Probl. Pediatr. Adolesc. Health Care 35, 6-24 (2005) 
200. Hammen, C., Brennan, P. A. \& Keenan-Miller, D. Patterns of adolescent depression to age 20: The role of maternal depression and youth interpersonal dysfunction. J. Abnorm. Child Psychol. 36, 1189-1198 (2008).

201. Lara, M. E., Leader, J. \& Klein, D. N. The association between social support and course of depression: Is it confounded with personality? J. Abnorm. Psychol. 106, 478 (1997).

202. Katz, S. J., Conway, C. C., Hammen, C. L., Brennan, P. A. \& Najman, J. M. Childhood Social Withdrawal, Interpersonal Impairment, and Young Adult Depression: A Mediational Model. J. Abnorm. Child Psychol. 39, 1227-1238 (2011).

203. Fawcett, J., Clark, D. C., Scheftner, W. A. \& Gibbons, R. D. Assessing anhedonia in psychiatric patients: the pleasure scale. Arch. Gen. Psychiatry 40, 79-84 (1983).

204. Nelson, J. C., Charney, D. S. \& Quinlan, D. M. Evaluation of the DSM-III criteria for melancholia. Arch Gen Psychiatry 38, 555-559 (1981)

205. Rush, A. J. \& Weissenburger, J. E. Melancholic symptom features and DSM-IV. Am J Psychiatry 151, 489-498 (1994).

206. Allen, L. B., Qian Lu, Tsao, J. C. I., Hayes, L. P. \& Zeltzer, L. $K$. Depression partially mediates the relationship between alexithymia and somatization in a sample of healthy children. J. Health Psychol. 16, 1177-1186 (2011).

207. Keenan, K., Feng, X., Hipwell, A. \& Klostermann, S. Depression begets depression: Comparing the predictive utility of depression and anxiety symptoms to later depression. J. Child Psychol. Psychiatry 50, 1167-1175 (2009).

208. Bress, J. N., Smith, E., Foti, D., Klein, D. N. \& Hajcak, G. Neural response to reward and depressive symptoms in late childhood to early adolescence. Biol. Psychol. 89, 156-162 (2012).

209. Chen, M. C., Burley, H. W. \& Gotlib, I. H. Reduced sleep quality in healthy girls at risk for depression: Sleep quality and risk for depression. J. Sleep Res. 21, 68-72 (2012).

210. Chua, H. C. et al. Ministry of Health clinical practice guidelines: depression. Singapore Med. J. 53, 137-43 (2012).

211. Goldman, S. Developmental epidemiology of depressive disorders. Child Adolesc. Psychiatr. Clin. N. Am. 21, 217-235 (2012).

212. Tompson, M. C., Boger, K. D. \& Asarnow, J. R. Enhancing the developmental appropriateness of treatment for depression in youth: integrating the family in treatment. Child Adolesc. Psychiatr. Clin. N. Am. 21, 345-384 (2012).

213. Grych, J. H. \& Fincham, F. D. Marital conflict and children's adjustment: a cognitive-contextual framework. Psychol. Bull. 108, 267 (1990).

214. Hanington, L., Heron, J., Stein, A. \& Ramchandani, P. Parental depression and child outcomes-is marital conflict the missing link? Child Care Health Dev. 38, 520-529 (2012).

215. Cummings, E. M., Goeke-Morey, M. C. \& Papp, L. M. Everyday marital conflict and child aggression. J. Abnorm. Child Psychol. 32, 191-202 (2004).
216. Du rocher schudlich, T. D. \& Cummings, E. M. Parental Dysphoria and Children's Internalizing Symptoms: Marital Conflict Styles as Mediators of Risk. Child Dev. 74, 1663-1681 (2003).

217. Du Rocher Schudlich, T. D. \& Cummings, E. M. Parental Dysphoria and Children's Adjustment: Marital Conflict Styles, Children's Emotional Security, and Parenting as Mediators of Risk. J. Abnorm. Child Psychol. 35, 627-639 (2007).

218. Aderka, I. M., Foa, E. B., Applebaum, E., Shafran, N. \& GilboaSchechtman, E. Direction of influence between posttraumatic and depressive symptoms during prolonged exposure therapy among children and adolescents. J. Consult. Clin. Psychol. 79, 421-425 (2011).

219. Wingo, A. P. et al. Moderating effects of resilience on depression in individuals with a history of childhood abuse or trauma exposure. J. Affect. Disord. 126, 411-414 (2010).

220. Davidson, R. J. Well-being and affective style: neural substrates and biobehavioural correlates. Philos. Trans.-R. Soc. Lond. Ser. B Biol. Sci. 1395-1412 (2004).

221. Murray, M. L., de Vries, C. S. \& Wong, I. C. K. A drug utilisation study of antidepressants in children and adolescents using the General Practice Research Database. Arch. Dis. Child. 89, 1098-1102 (2004).

222. Wijlaars, L. P., Nazareth, I. \& Petersen, I. Trends in depression and antidepressant prescribing in children and adolescents: a cohort study in The Health Improvement Network (THIN). PLoS One 7, e33181 (2012).

223. Emslie, G. J. Understanding placebo response in pediatric depression trials. Am. J. Psychiatry 166, 1-3 (2009).

224. Clavenna, A. et al. Antidepressant and antipsychotic use in an Italian pediatric population. BMC Pediatr. 11, 40 (2011).

225. Stark, P. \& Hardison, C. D. A review of multicenter controlled studies of fluoxetine vs. imipramine and placebo in outpatients with major depressive disorder. J. Clin. Psychiatry (1985). at $<$ http://psycnet.apa.org/psycinfo/1986-07250-001>

226. Hazell, P., O'Connell, D., Heathcote, D. \& Henry, D. A. Tricyclic drugs for depression in children and adolescents. Cochrane Libr. (2002). at <http://onlinelibrary.wiley.com/ doi/10.1002/14651858.CD002317/full>

227. Keller, M. B. et al. Efficacy of paroxetine in the treatment of adolescent major depression: a randomized, controlled trial. J. Am. Acad. Child Adolesc. Psychiatry 40, 762-772 (2001).

228. Emslie, G. J. et al. Fluoxetine for acute treatment of depression in children and adolescents: a placebo-controlled, randomized clinical trial. J. Am. Acad. Child Adolesc. Psychiatry 41, 12051215 (2002).

229. Hammad, T. A., Laughren, T. \& Racoosin, J. Suicidality in pediatric patients treated with antidepressant drugs. Arch. Gen. Psychiatry 63, 332-339 (2006).

230. Stone, M. et al. Risk of suicidality in clinical trials of antidepressants in adults: analysis of proprietary data submitted to US Food and Drug Administration. Bmj 339, (2009). 
231. Nakonezny, P. A. et al. A comparison of various methods of measuring antidepressant medication adherence among children and adolescents with major depressive disorder in a 12-week open trial of fluoxetine. J. Child Adolesc. Psychopharmacol. 20, 431-439 (2010).

232. Tao, R., Emslie, G. J., Mayes, T. L., Nakonezny, P. A. \& Kennard, B. D. Symptom improvement and residual symptoms during acute antidepressant treatment in pediatric major depressive disorder. J. Child Adolesc. Psychopharmacol. 20, 423-430 (2010).

233. Santarelli, L. et al. Requirement of hippocampal neurogenesis for the behavioral effects of antidepressants. Science 301, 805-809 (2003).

234. Czéh, B. et al. Stress-induced changes in cerebral metabolites, hippocampal volume, and cell proliferation are prevented by antidepressant treatment with tianeptine. Proc. Natl. Acad. Sci. 98, 12796-12801 (2001).

235. Frodl, $T$. et al. Effect of hippocampal and amygdala volumes on clinical outcomes in major depression: a 3-year prospective magnetic resonance imaging study. J. Psychiatry Neurosci. JPN 33, 423 (2008).

236. Hetrick, S. E., McKenzie, J. E., Cox, G. R., Simmons, M. B. \& Merry, S. N. Newer generation antidepressants for depressive disorders in children and adolescents. Cochrane Libr. (2012). at $\quad<$ http://onlinelibrary.wiley.com/doi/10.1002/14651858. CD004851.pub3/full>

237. Mitchell, A. M., Davies, M. A., Cassesse, C. \& Curran, R. Antidepressant Use in Children, Adolescents, and Young Adults: 10 Years After the Food and Drug Administration Black Box Warning. J. Nurse Pract. 10, 149-156 (2014).

238. McCullough, M. E. \& Larson, D. B. in (1998). at <http:// psycnet.apa.org/psycinfo/1998-06536-007>

239. McCullough, M. E. \& Larson, D. B. Religion and depression: a review of the literature. Twin Res. 2, 126-136 (1999).

240. Koenig, H. G., McCullough, M. E. \& Larson, D. B. Handbook of Religionand Health. (2001).

241. Kasen, S., Wickramaratne, P., Gameroff, M. J. \& Weissman, M. M. Religiosity and resilience in persons at high risk for major depression. Psychol. Med. 42, 509-519 (2012).

242. Kohrt, B. A. et al. Validation of cross-cultural child mental health and psychosocial research instruments: adapting the Depression Self-Rating Scale and Child PTSD Symptom Scale in Nepal. BMC Psychiatry 11, 127 (2011).

243. Bhatia, S. K. \& Bhatia, S. C. Childhood and adolescent depression. Am. Fam. Physician 75, 73-80 (2007).

244. Chang, H.-J., Zauszniewski, J. A., Heinzer, M. M., Musil, C. M. \& Tsai, W.-C. Adaptive functioning and depressive symptoms in school-aged children. J. Adv. Nurs. 60, 502-512 (2007).
245. Harrington, R. C. Adult outcomes of childhood and adolescent depression: Influences on the risk for adult depression. Psychiatr. Ann. (1996). at <http://psycnet.apa.org/ psycinfo/1996-05071-003>

246. Brown, R. T. et al. Childhood mental health disorders: Evidence base and contextual factors for psychosocial, psychopharmacological, and combined interventions. (American Psychological Association, 2008), at <http://doi. apa.org/?uid=2007-15067-000>

247. Fishbein, D., Novak, S. P., Krebs, C., Warner, T. \& Hammond, J. The mediating effect of depressive symptoms on the relationship between traumatic childhood experiences and drug use initiation. Addict. Behav. 36, 527-531 (2011).

248. Donovan, C. L. \& Spence, S. H. Prevention of childhood anxiety disorders. Clin. Psychol. Rev. 20, 509-531 (2000).

249. Kösters, M. P. et al. Study design of'FRIENDS for Life': process and effect evaluation of an indicated school-based prevention programme for childhood anxiety and depression. BMC Public Health 12, 86 (2012).

250. Costello, E. J., Mustillo, S., Erkanli, A., Keeler, G. \& Angold, A. Prevalence and development of psychiatric disorders in childhood and adolescence. Arch. Gen. Psychiatry 60, 837844 (2003).

251. Trompetter, I., Krick, B. \& Weiss, G. Herbal triplet in treatment of nervous agitation in children. Wien. Med. Wochenschr. 163, 52-57 (2013).

252. Hammen, C., Brennan, P. A. \& Le Brocque, R. Youth depression and early childrearing: stress generation and intergenerational transmission of depression. J. Consult. Clin. Psychol. 79, 353 (2011).

253. Asarnow, J. R. et al. Depression and role impairment among adolescents in primary care clinics. J. Adolesc. Health 37, 477483 (2005).

254. Fergusson, D. M. \& Woodward, L. J. Mental health, educational, and social role outcomes of adolescents with depression. Arch. Gen. Psychiatry 59, 225-231 (2002).

255. Hammen, C. Stress and depression. Annu Rev Clin Psychol 1, 293-319 (2005)

256. Kim, E. Y. \& Miklowitz, D. J. Expressed emotion as a predictor of outcome among bipolar patients undergoing family therapy. J. Affect. Disord. 82, 343-352 (2004).

257. Johnson, L., Lundström, O., \AAberg-Wistedt, A. \& Mathé, A. A. Social support in bipolar disorder: its relevance to remission and relapse. Bipolar Disord. 5, 129-137 (2003).

258. Miklowitz, D. J. et al. Expressed emotion moderates the effects of family-focused treatment for bipolar adolescents. J. Am. Acad. Child Adolesc. Psychiatry 48, 643-651 (2009). 
259. Grant, K. E. et al. Stressors and child and adolescent psychopathology: moving from markers to mechanisms of risk. Psychol. Bull. 129, 447 (2003).

260. Masia-Warner, C., Nangle, D. W. \& Hansen, D. J. Bringing evidence-based child mental health services to the schools: General issues and specific populations. Educ. Treat. Child. 165-172 (2006).

261. Neil, A. L. \& Christensen, H. Efficacy and effectiveness of school-based prevention and early intervention programs for anxiety. Clin. Psychol. Rev. 29, 208-215 (2009).

262. Stone, L. B., Uhrlass, D. J. \& Gibb, B. E. Co-rumination and lifetime history of depressive disorders in children. J. Clin. Child Adolesc. Psychol. 39, 597-602 (2010).

263. Rose, A. \& Rudolph, K. A review of sex differences in peer relationship processes: Potential tradeoffs for the emotional and behavioral development of girls and boys. Psychological Bulletin 132, 98-131 (2006)

264. Barrett, P. FRIENDS for Life: Group Leader's Manual for Children. Aust. Acad. Press (2004).

265. Barrett, P. FRIENDS for Life: Workbook for Children Australia. Aust. Acad. Press (2004).

266. Utens, E. \& Ferdinand, R. VRIENDEN voor het Leven: handleiding voor groepsleiders voor kinderen Rotterdam: Afdeling Kinder - en Jeugdpsychatrie. Erasmus Med. Cent. Rotterdam - Sophia Kinderziekenhuis (2006)

267. Utens, E. \& Ferdinand, R. VRIENDEN voor het Leven: werkboek voor kinderen Rotterdam: Afdeling Kinder - en Jeugdpsychiatrie. (2006).

268. DeGarmo, D. S., Reid, J. B., Leve, L. D., Chamberlain, P. \& Knutson, J. F. Patterns and Predictors of Growth in Divorced Fathers' Health Status and Substance Use. Am. J. Mens Health 4, 60-70 (2010).

269. Sheeber, L. B. et al. Dynamics of affective experience and behavior in depressed adolescents. J. Child Psychol. Psychiatry 50, 1419-1427 (2009)

270. Rudolph, K. D., Hammen, C. \& Burge, D. A cognitiveinterpersonal approach to depressive symptoms in preadolescent children. J. Abnorm. Child Psychol. 25, 33-45 (1997).

271. Tick, N., van der Ende, J. \& Verhulst, F. Ten-year increase in service use in the Dutch population. Eur Child Adolesc Psychiatry 17, 373-380 (2008).

272. Verhulst, F. \& van der Ende, J. Factors associated with child mental health service use in the community. J Am Acad Child Adolesc Psychiatry 36, 901-909 (1997)

273. Zwaanswijk, M., van der Ende, J., Verhaak, P., Bensing, J. \& Verhulst, F. Help-seeking for child psychopathology: pathways To informal and professional services in the Netherlands. J Am Acad Child Adolesc Psychiatry 1292-1300 (2005).
274. White, J. in In The troubled adolescent 111-142 (Pergamon Press, 1989).

275. Kovacs, M. Children's depression inventory manual. (Western Psychological Services, 1992).

276. Timbremont, B., Braet, C. \& Dreessen, L. Assessing depression in youth: Relation between the Children's Depression Inventory and a structured interview. J. Clin. Child Adolesc. Psychol. 33, 149-157 (2004).

277. McCauley, E., Pavlidis, K. \& Kendall, K. in The depressed child and adolescent 2, 46-78 (2001)

\section{Comment on this article:}

\section{8 in $8+\mathbf{S} P$}

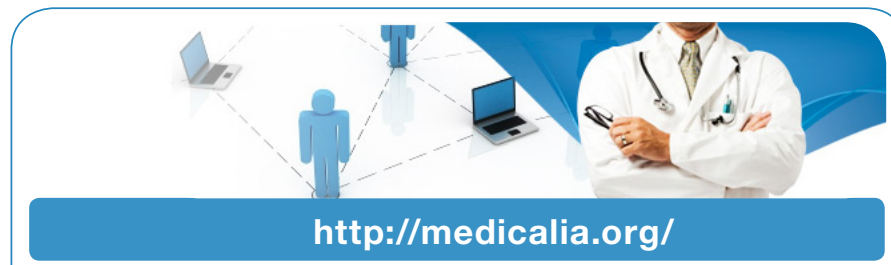

Where Doctors exchange clinical experiences, review their cases and share clinical knowledge. You can also access lots of medical publications for free. Join Now!

\section{Publish with iMedPub}

http://www.imed.pub

International Archives of Medicine is an open access journal publishing articles encompassing all aspects of medical science and clinical practice. IAM is considered a megajournal with independent sections on all areas of medicine. IAM is a really international journal with authors and board members from all around the world. The journal is widely indexed and classified Q1 in category Medicine. 